\title{
The role of fire within Neolithic collective burials: Spatial analyses of cremains from the site of $\mathrm{La}$ Truie Pendue, France
}

\section{Camille de Becdelievre, Sandrine Thiol, Laure Saligny, Ludovic Granjon \& Stéphane Rottier}

To cite this article: Camille de Becdelievre, Sandrine Thiol, Laure Saligny, Ludovic Granjon \& Stéphane Rottier (2016) The role of fire within Neolithic collective burials: Spatial analyses of cremains from the site of La Truie Pendue, France, Journal of Field Archaeology, 41:5, 550-567, DOI: 10.1080/00934690.2016.1219209

To link to this article: http://dx.doi.org/10.1080/00934690.2016.1219209

View supplementary material $₫$

曲 Published online: 06 Sep 2016.

Submit your article to this journal $2 \pi$

山 Article views: 6

Q View related articles $₫$

View Crossmark data $₫$ 


\title{
The role of fire within Neolithic collective burials: Spatial analyses of cremains from the site of La Truie Pendue, France
}

\author{
Camille de Becdelievre ${ }^{1}$, Sandrine Thiol ${ }^{2}$, Laure Saligny33, Ludovic Granjon ${ }^{3} \odot$, \\ Stéphane Rottier 4
}

${ }^{1}$ Department of Archaeology, University of Belgrade, Belgrade, Serbia, ${ }^{2}$ Institut national de recherches
archéologiques préventives, Reims, France, ${ }^{3}$ Université de Bourgogne-CNRS, Dijon, France, ${ }^{4}$ Université de
Bordeaux CNRS, Pessac, France

The use of collective graves is one of the main features of the western European Late Neolithic. A single gravesite received the successive deposition of dozens or sometimes hundreds of individuals. While cremations or even full-fired inhumation layers are often found within these funerary deposits, the actual role of fire is still poorly understood. Recently discovered within the important archaeological complex of Passy (Yonne, France), the burned collective grave of La Truie-Pendue provides an outstanding case study to examine the use of fire within Neolithic funerary rites. In this study, we develop a new contextual approach to bone alterations in order to reconstruct the original circumstances of combustion and to examine cultural motivations for the use of fire. Results of spatial statistical analyses indicate that the fire event was the first step of a procedure that sealed the grave, closed the access to the dead and signaled the end of the grave's history. Similar sealing procedures were usual elsewhere during the Late Neolithic. Finally, this study demonstrates the value of using GIS as a tool to optimize taphonomic analyses of widely fragmented and commingled skeletal assemblages.

Keywords: burned bones, Neolithic collective grave, GIS, osteoarchaeology, burial taphonomy

\section{Introduction}

The use of collective graves is one of the main features of the western European Late Neolithic. This type of burial became widespread from Scandinavia to the Iberian Peninsula, persisting for over almost two millennia (4th and 3rd millennium B.C.). Although these graves comprised diverse shapes and materials (e.g., simple pits, tumuli, megaliths, hypogea), the principle of inhumation was shared; over decades, a single gravesite received the successive depositions of multiple corpses, varying from a few individuals to hundreds (Leclerc and Tarrête 1988). Long-term use of collective graves may have prompted the communities to manage their funerary spaces in different ways, including the processing of corpses (Leclerc 1996; Chambon 2003). Such a palimpsest of human behaviors often results in commingled and fragmented skeletal assemblages, rendering it difficult to differentiate between gestures intended for practical purposes from those involving symbolic beliefs.

Correspondence to: Camille de Becdelievre, 2 Impasse de l'enclos, 30650, Saze, France. Email: c.debecdelievre@gmail.com.
Of particular interest is the use of fire by Neolithic communities within funerary rites involving collective graves. Numerous burials have yielded burned remains, whether in the form of human cremations, or more frequently, calcined architectural elements or even full-fired inhumation layers (Masset 2002). The polymorphic presence of fire in collective graves leads to questions concerning the role assigned to this element by late prehistoric people in their funerary deposits (Gatto 2007). Was fire used as a simple tool to process corpses, as a destructive technique to remove graves, or was it used in the context of symbolic ritual?

The recent discovery of a burned collective grave at La Truie Pendue (Passy-Véron, France), provides a case study to tackle the issue of fire usage within the Neolithic funerary rite. Between 2006 and 2007, the remains (henceforth, cremains) of at least 65 individuals were exhumed from a (restored) wooden structure dated to the Late Neolithic (Thiol et al. 2010; Le Roy et al. 2014). The nature of the assemblage, fragmented and commingled, and the external aspect of bones, distorted and colorful, suggest that an intense episode of fire took place while the burial was still in use (de Becdelievre et al. 2015). Rather than being an 
impediment for analyzing the dynamic of the burial, these heat signatures provide valuable evidence for reconstructing the fire episode and thereby for better understanding the motivations underlying the use of fire in a Neolithic collective deposit.

Considering the fragmented and commingled nature of the skeletal assemblage, we developed a Geographic Information System (GIS) to manage and analyze the cremains. Indeed, the potential of GIS to "integrate both attributes and spatial data" and to "identify spatial trends" (Gallotti et al. 2011: 373) particularly suited our interest in taphonomy by allowing us to "integrate different physical alterations" (attribute data) and to map their distributions (spatial data), in order to "reconstruct the dynamic of the fire" (spatial trend) throughout the burial sequence. Our aim was a better understanding of the role of fire in the funerary practices of a Neolithic community.

\section{Material and Methods}

\section{Archaeological background: A burned collective grave}

The site of La Truie Pendue is part of a wider archaeological area discovered in the municipalities of Passy and Véron (Yonne, France), on the right bank of the Yonne River (Carré 1985; Müller et al. 1997; Depierre et al. 1997). Discovered at Richebourg and at La Sablonière, Middle Neolithic elongated funerary buildings considered the first monumental cemeteries of western Europe are known as the Passy type (Chambon and Thomas 2010). Between 2006 and 2007, several monuments dated to the Middle and Late Neolithic were excavated by R. Labaune and were reminiscent of Middle Neolithic Passy type monuments (Online Supplement). The number of funerary structures from the Middle Neolithic (Passy type monuments) to the Bronze Age (secondary deposits of cremations) discovered in this area of the Paris Basin show diversity in terms of funerary behaviors but also strong local specificities. Several graves were found during the recent excavations of the site of Passy-Véron: three burials (simple inhumations) within monuments, three burials (simple inhumations) outside the monuments, a double burial, a collective grave and a pit with cremated bones. The collective grave was discovered in the eastern part of a quadrangular monument evidenced by 29 post holes (Lecornué et al. 2009), while the burial of a young child was uncovered near the western part of the building (FIG.

1) (Online Supplement) (Desbat et al. 2011).

Dated to 3360-3098 CAL B.C. (LY-5277, 4524 \pm 30 B.P.; Intcal 04; material dated: human bone sampled from the top of the grave) La Truie Pendue is from the beginning of the Late Neolithic, a period known for the increasing number of collective graves in the Paris Basin. Oriented northwest by southeast, the grave measured $2.80 \mathrm{~m}$ long by $1.60 \mathrm{~m}$ wide and about $0.60 \mathrm{~m}$ deep. Taphonomic analyses indicate the former presence of a quadrangular wooden structure (Thiol et al. 2010), probably protected by a removable opening system which provided the community constant access to its dead (FIG. 1A); these types of wooden structures are well-documented in the Paris Basin (Chambon 2003), the closest example (in terms of geography and typology) being the deposit of Pont-sur-Yonne Le Bas des Renardières (located only $20 \mathrm{~km}$ from La Truie Pendue) (Prampart 1983). The grave contained the remains of at least 65 individuals discovered in different states of preservation: a compact mass of commingled and fragmented bones comprising the upper layers and 13 anatomically-connected skeletons comprising the lower layers (Le Roy et al. 2014) (FIG. 1, 2A). Within the lower layers, five successive levels of top to tail interments have been distinguished, the bodies being alternately oriented North to South and South to North (FIG. 2A). The numerous overlapping and interweaving bones suggest the close or quasi-simultaneous deposition of these 13 individuals during initial use of this grave. In the upper layers, disconnected and fragmented bone remains demonstrate different sorts of alterations, such as shrinkage, twisting and warping. Of particular note is the concentric distribution within the deposit of various colors, from white to gray and brown to dark black (FIG. 1B), with some remains having turquoise stains. In addition to human cremains, reddish sediment (found above, on the sides and below the assemblage) indicates an intense episode of fire from the top to the bottom of the skeletal assemblage. Below the skeletal assemblage, areas of darker sediment also suggest the possible combustion of some wooden architectural element (the bottom of the wooden structure?). Similarly, 26\% of lithic tools yielded evidence of having been subjected to heat (Thiol et al. 2010).

Results from a preliminary analysis performed on several black phalanges from the deeper burial layers indicate that their dark color is not correlated to impregnation of the bone by organic residues or to the presence of metal oxides in the sediment. Instead, the coloration can be explained by "moderate subjection to heat" (Thiol et al. 2010: 162-163). Using a microscope photometer, small degassing vesicles as well as small fluorescent droplets have been observed on bone surfaces. These features were interpreted as indicators of the partial combustion of the organic components of bones.

Above the concentric color gradient, a substantial layer of blocks and sediment covered the deposit (FIG. 1A). Although the upper part of this layer does not show evidence of combustion, the sediment immediately covering the cremains was reddened. 


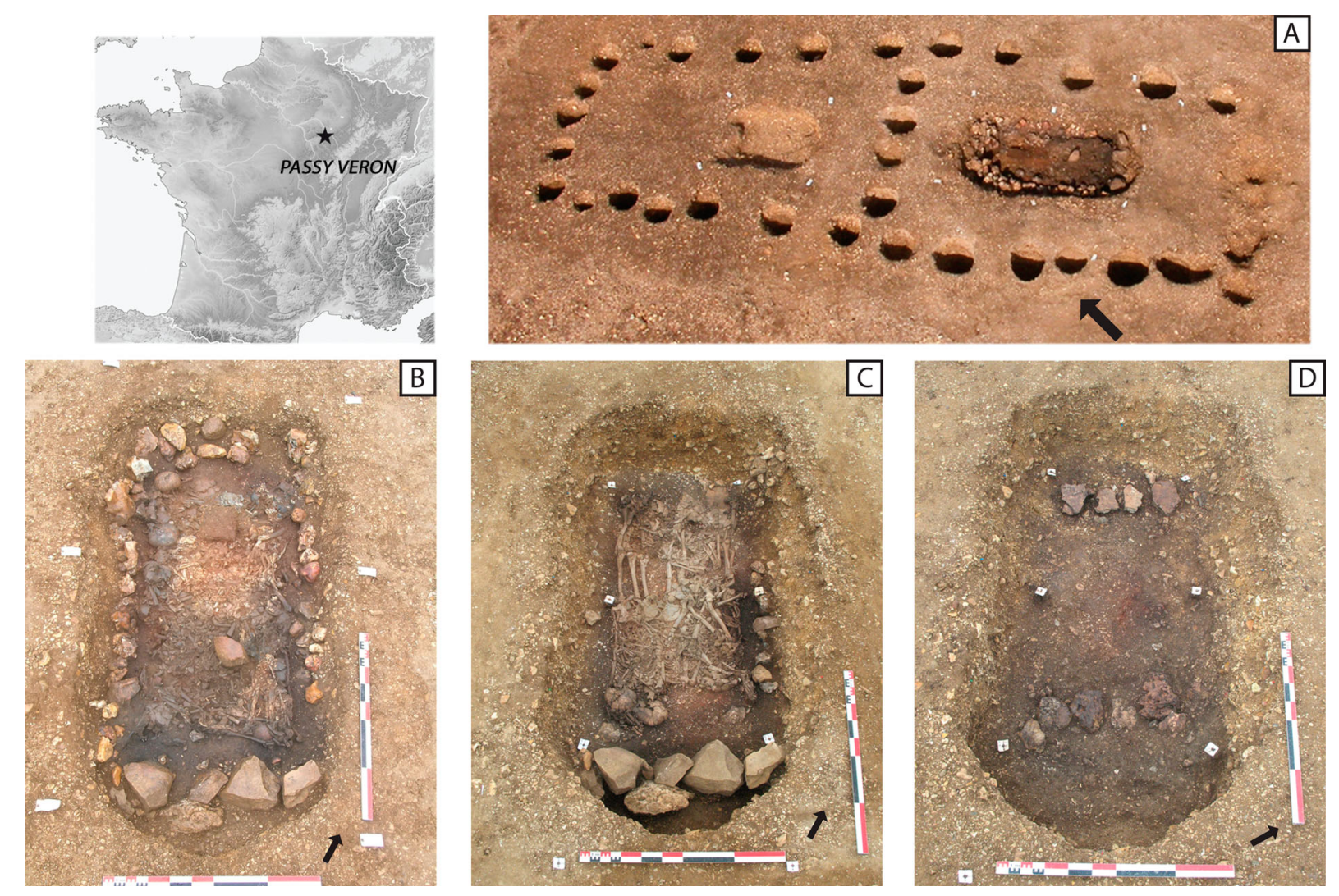

Figure 1 Views of the collective burial of La Truie Pendue: A) The burial chamber, inside a quadrangular building; B) In the upper part of the skeletal assemblage a compact mass of cremains encompass a gradient of colors; the alignment of flints along the pit walls suggests the presence of a wooden structure; a lateral range of sandstone blocks was perhaps aimed at sustaining a removable opening system; C) Anatomically-connected skeletons, in the deeper layer of the assemblage; D) Traces of combustion recorded under the skeletal assemblage. Photographs Copyright INRAP.

Some sandstones pieces and flint blocks from this layer yielded red plaques and thermal cupules that suggest they had been subjected to heat. Considering these elements, we hypothesize the hearth was covered, while still hot, by the stones and sediment.

Similar sealing layers, comprising stone blocks and sediment, have been documented in other collective burials in the Paris Basin: at Les Mournouards, La Chaussée Tirancourt, and La Croix Saint Ouen. This final layer may have been intended to definitively close access to the dead, signaling the end of the burial deposits (Leclerc 1987; Masset 2002; Rojo Guerra and Kunst 2002). Interestingly, a later circular pit $0.70 \mathrm{~m}$ in diameter, has been documented in the eastern part of the assemblage of La Truie Pendue. From the top of the deposit to the bottom of the skeletal assemblage, blocks were driven into the assemblage, disturbing the color gradient and the skeletons' anatomical connections.

Considering the complex taphonomy of the assemblage, which indicates both intense combustion (reddish sediment, bone coloration and warping) and heterogeneous heat diffusion (two different layers of fragmentation, and partial combustion in the bottom of the pit), and the absence of charcoal remains (only 10 grams of charcoal were collected despite systematic flotation of the whole sediment of the structure), the authors sought to unravel the original conditions of the fire and the process of the combustion before performing any further bioarchaeological analyses.

\section{An integrated approach to interpreting burned bones}

In a pilot study conducted on a subsample of 200 cremains from the site of La Truie Pendue, several of us set up the framework for an integrated approach to the burned bones' physical alterations (de Becdelievre et al. 2015) (FIG. 3). From a review of the state of research on burned bones, three groups of alterations were selected in order to infer the original heating conditions: bone external alterations (color changes); bone mechanical alterations (warping, cracking, fracturing and fragmentation); and bone internal alterations (chemical changes that can be empirically assessed through the toughness and resonance of cremains). An important limitation in the use of these alterations to infer the original circumstances of combustion was recognized: physical alterations may be caused simultaneously by several variables (FIG. 3). To circumvent this bias, it was decided to perform both contextual and multifactorial 


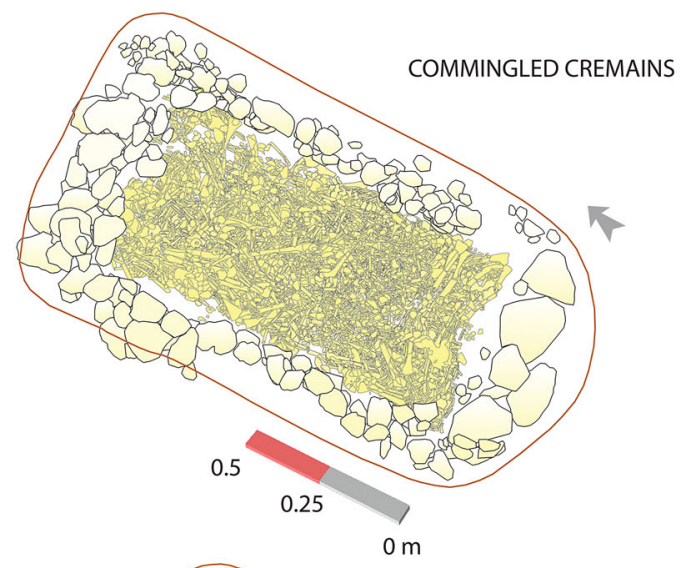

A
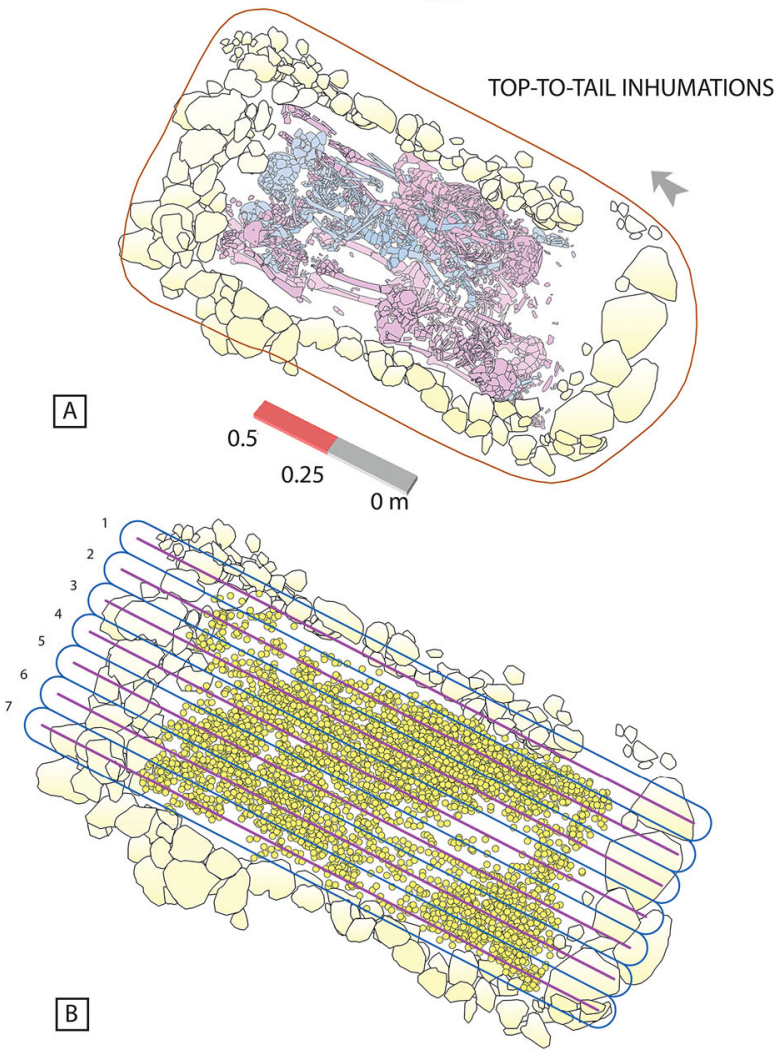

Figure 2 GIS views. A) The different layers observed during the excavations; B) GIS data management: all levels of records were combined in a single one, cremains were turned into centroids and seven vertical profiles were set (with associated buffers) to perform spatial statistical analyses.

analyses of physical alterations (TABLE 1) (see de Becdelievre et al. 2015: table 2), to examine simultaneously several markers (i.e., to examine groups of physical alterations) to consider the possible impact of the various circumstances of combustion (intensity, atmosphere, and maintenance of the combustion as well as states of decomposition of the bodies).

During this preliminary study, a non-random vertical distribution of cremains color, warping, toughness and resonance was observed, leading the authors to hypothesize that the fire was lit on the upper part of the burial where remains were not yet buried (i.e., still accessible for the community); it burned in an oxygen rich environment and reached high temperatures; the deeper part of the burial burnt in a more reducing environment and did not reach high temperatures; the presence of an impediment to downward heat diffusion suggests that two different funerary layers were maybe separated within the burial sequence; bodies with soft tissues perhaps fed the intense combustion in the upper part of the burial whereas corpses buried in the deeper layers were certainly already skeletonized.

To test these hypotheses, physical alterations were scored on each of the cremains from the assemblage and their spatial distributions compared throughout the whole burial sequence. Considering the difficulty of objectively scoring cracks, fractures, toughness and resonance, we restricted use of these markers to analyses of the subsample and focus the present paper on the distribution of colors, warping, and fragmentation. Colors and warping were scored according to the categories defined by de Becdelievre and colleagues (2015); the level of fragmentation was computed by comparing cremains' average weights and cremains' average sizes through the burial sequence. Since the secondarily disturbed area might bias the reconstruction of the fire, bones from this area have been excluded from this study.

\section{A GIS-based study}

Given the large amount of highly fragmented cremains (10,679 bone remains), we used GIS to facilitate analyses. Operating as a spatial database management system (Gilbert 2008), GIS is a "powerful set of tools for collecting, storing, retrieving at will, transforming and displaying spatial data from the real world for a particular set of purposes" (Burrough and McDonnell 1998: 11). The system integrates geographically referenced data of different types, including alphanumeric (attribute information) or graphic (geometric information). Data are organized in interrelated layers such that analyses can involve both spatial relationships of remains and their descriptive attributes. GIS offers the opportunity to manage large archaeo-anthropological databases, as well as to cross biological, taphonomic and spatial features of cremains through their selective and/or contextual treatment. For example GIS-based methods have been applied to the analyses of a burned bioarchaeological assemblage in the study of the Walker Noe site (Garrad County, Kentucky), a prehistoric mound crematory (Herrmann et al. 2005; Devlin and Herrmann 2008; Herrmann and Devlin 2008). Using a modified version of the BoneEntryGIS software extension for ArcGIS (Marean et al. 2011), bone fragments were digitized and recorded by location, fracture pattern, color density, and biological characteristics. Herrmann and Devlin (2008) highlighted the important contribution of this system to documenting 


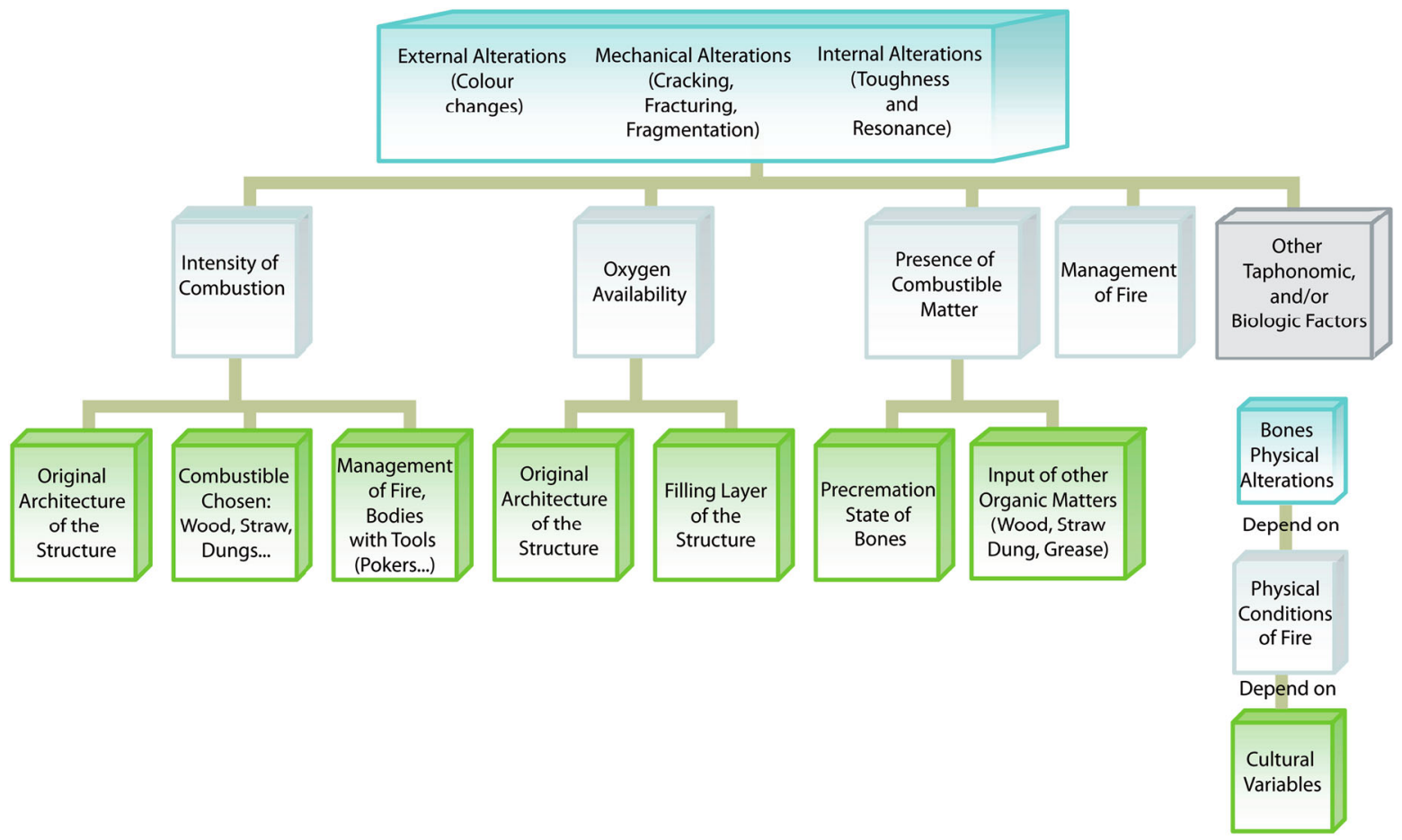

Figure 3 The inference approach: from bone alterations to the original circumstances of the fire and the original state of the archaeological structure.

highly fragmented bioarchaeological deposits. Although innovative, we regret that the BoneEntryGIS extension considers bone locations as an attribute variable, restricting contextual analyses. Across the Walker Noe site, the locations of cremains are restricted two area- "the core area" and "the periphery"-blurring more complex spatial patterns. Following their GIS and intra-site approach, we added an actual spatial dimension to the analysis by mapping each cremain in order to reconstruct the spatial dynamics of the combustion within the grave.

All spatial analyses were performed using ArcGis software. The whole deposit was treated on field using the same protocol that would have been required for the excavations of an immense cremation (Duday
2009); the excavations of 24 artificial layers of bones were necessary (Thiol et al. 2010). After the excavation of a layer, a photograph was systematically taken and each fragment appearing on the photograph was collected, directly identified with a unique ID number and isolated on the photograph before proceeding to the excavation of the next layer. After the excavations, each photograph was digitized and then imported on ArcGIS. Spatially referenced landmarks located around the grave were used to adjust each of the 24 layers. Each bone fragment was considered as a polygon and its ID number was used as a key to associate polygons within the attribute database. The attribute database describes each bone fragment with its basic biological and taphonomic characteristics.

Table 1 The scoring system and the contextual approach followed during our analyses. Several physical markers are examined together through spatial analyses to distinguish broad stages of combustion, in view of clarifying the circumstances of combustion.

\begin{tabular}{|c|c|c|c|}
\hline $\begin{array}{l}\text { Circumstances of } \\
\text { combustion }\end{array}$ & Defined stages & Operable physical markers & Spatial analyses \\
\hline Intensity of combustion & $\begin{array}{l}\text { High intensity } \\
\text { Medium intensity } \\
\text { Low intensity }\end{array}$ & $\begin{array}{l}\text { From yellow-white to turquoise, } \\
\text { warped bones } \\
\text { From white to gray } \\
\text { From yellow to brown and black }\end{array}$ & $\begin{array}{l}3 \text { dimensional scatterplots of cremain colors } \\
\text { Interpolation of cremain colors }\end{array}$ \\
\hline $\begin{array}{c}\text { Atmosphere of } \\
\text { combustion }\end{array}$ & $\begin{array}{l}\text { Oxidizing atmosphere } \\
\text { Reducing atmosphere }\end{array}$ & $\begin{array}{l}\text { Light hues } \\
\text { Dark hues }\end{array}$ & $\begin{array}{l}\text { Distribution and density analyses on } \\
\text { horizontal and vertical profiles }\end{array}$ \\
\hline $\begin{array}{l}\text { Precombustion state of } \\
\text { bones }\end{array}$ & $\begin{array}{l}\text { Body burned fresh } \\
\text { Body burned already } \\
\text { skeletonized }\end{array}$ & $\begin{array}{l}\text { White and gray-blue, warping } \\
\text { Tanned colors absence of } \\
\text { warping }\end{array}$ & $\begin{array}{l}\text { Distribution and density analyses on } \\
\text { horizontal and vertical profiles }\end{array}$ \\
\hline $\begin{array}{l}\text { Maintenance of } \\
\text { combustion }\end{array}$ & $\begin{array}{l}\text { Managed fire } \\
\text { Non-managed fire }\end{array}$ & $\begin{array}{l}\text { High level of fragmentation and } \\
\text { dispersion } \\
\text { Low level of fragmentation and } \\
\text { dispersion }\end{array}$ & $\begin{array}{l}\text { Level of fragmentation } \\
\text { Dispersion analyses }\end{array}$ \\
\hline
\end{tabular}


Table 2 Horizontal profiles defined throughout the burial sequence based on threshold elevation values corresponding to stratigraphic breaks observed during the excavations.

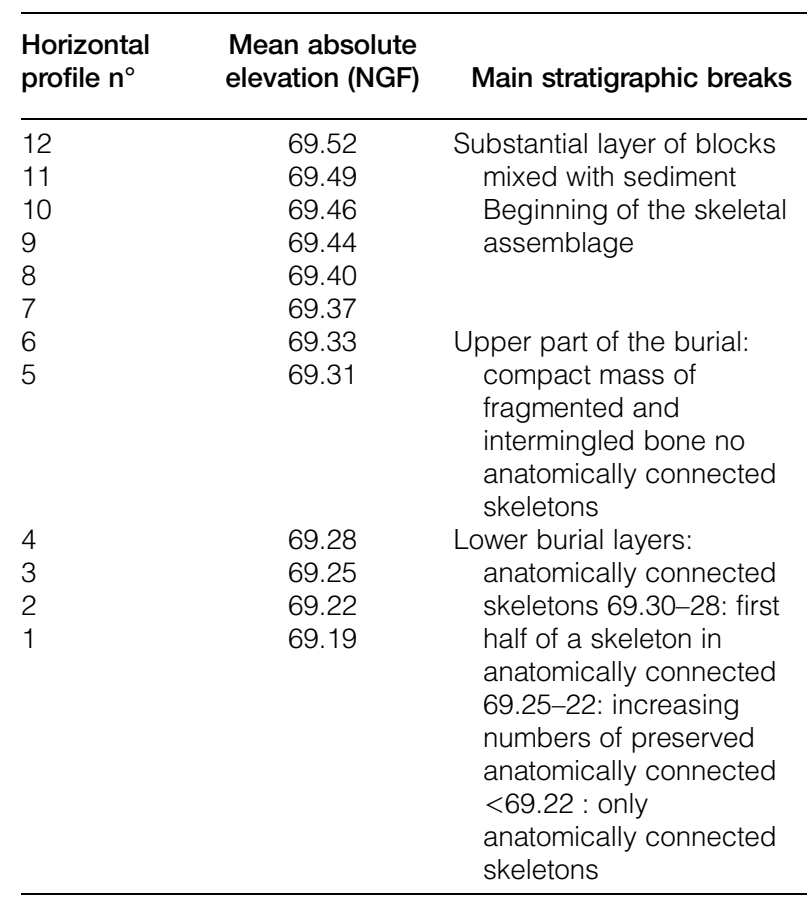

Midpoint coordinates of individual polygons could then be extracted, allowing consideration of bone centroids, more suitable to most geostatistical analytic tools (FIG. 2B). Finally, all spatial layers could be combined and the excavation grid could be vertically and horizontally reset according to the required scale of analysis (FIG. 2A,B). As stated above, from the original assemblage we excluded cremains from the secondarily disturbed area and fragments discovered during flotation, since these data cannot be visualized. The global analysis focused on 3771 remaining bones or fragments.

\section{Spatial analyses}

A fire can be defined as a sequence of exothermic reactions occurring between a fuel and an oxidant (the conditions), which generates and diffuses heat (the dynamic) (Dehaan 2008). Therefore, we first examined the original conditions that enabled the process of combustion - the availability of oxygen and the presence of fuel-and then reconstructed the course of the fire throughout the burial sequence.

To examine oxygen availability within the assemblage, we compared the distribution of turquoise, white and yellow-white remains as reliable indicators of a rather oxidizing heating environment, and the distribution of "dark black remains as reliable indicators of a 'rather reducing' heating environment" (TABLE 1) (Lisowski 1968; Herrmann 1972; Perinet 1982; Stiner et al. 1995; Walker et al. 2008). Sources of combustion fuel in the grave can be both external (e.g., branches, leaves, animal fats, dungs) and internal (e.g., wooden posts or the structure enclosing the assemblage, the buried bodies' fats). Considering that almost no remains of charcoal were found during the excavations, human corpses are the only evidence of a fuel source that can be assessed a posteriori (FIG. 3). Since the fuel power of fresh corpses (i.e., with soft tissues, body fluids, fat, muscles and marrow) is much more significant than the fuel power of dry skeletons (i.e., already more mineral than organic), we discuss the presence and location of "fresh corpses" by comparing the distribution of warped, white and blue-gray markers (TABLE 1) (on the use of white, blue, gray and warping as markers of bodies state of decomposition see Baby 1954; Binford 1963; Thurman and Willmore 1980; Buikstra and Swegle 1989; Guillon 1987; Grévin 2002; Nawrocki 2003; Baker Bontrager and Nawrocki 2008; Schultz et al. 2008; Symes et al. 2008; Walker et al. 2008; Depierre 2010).

To perform spatial analyses, we utilized 12 horizontal and seven vertical profiles covering the whole assemblage (FIGS. 2B, 4) (TABLE 2). Given the nature of the skeletal assemblage, a compact mass of bone remains, it was impossible to record in the field a complete vertical section of the burial; GIS-based techniques make possible data visualization on such projections. To provide a clear spatial distribution of bioarchaeological markers within the commingled deposit, data were projected on vertical and horizontal sections and subsequently smoothed using Kernel Density Estimation (KDE) of each marker. Smoothing parameters were selected empirically: cells of $0.025 \mathrm{~m}$ and a bandwidth of $0.05 \mathrm{~m}$, values which allow for significant smoothing without substantial data loss. Resulting data were output by the standard deviations to produce equal classes of density that enabled comparisons among maps; this classification was finally turned into density classes increasing from 1 to 5 (FIGS. 5, 6).

To discuss heat intensity, we focused on cremain colours (TABLE 1) (for the associations between physical markers and reached temperatures see Bonucci and Graziani 1975; Shipman et al. 1984; Susini 1988; Wahl 1981; Stiner et al. 1995; Symes et al. 1996;

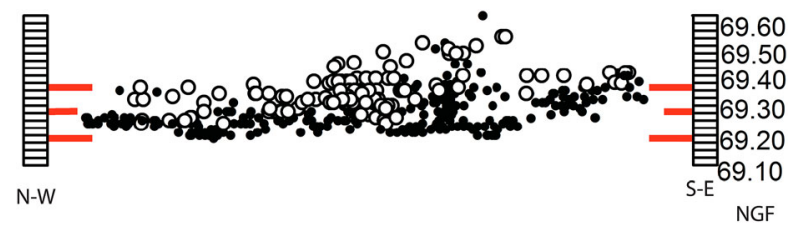

- Light colors (Yellowish, White, Turquoise)

- Dark colors (Black Dark, Brown-Grey)

Figure 4 GIS distribution analyses. Distribution of dark cremains vs. light cremains within the grave; cremains are plotted on a synthetic vertical profile. 

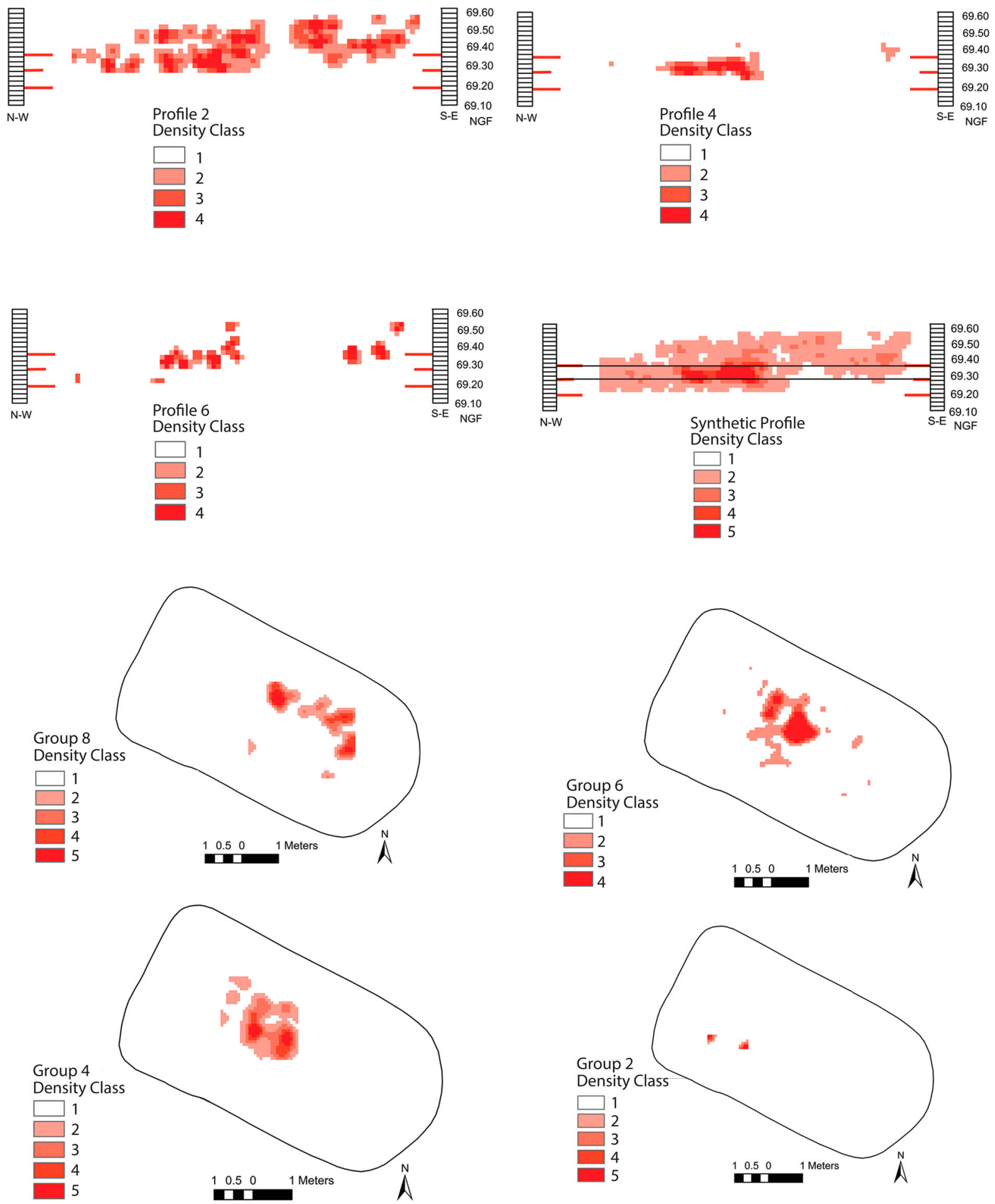

Figure 5 GIS spatial analyses. Kernel density analyses of yellow-white, white and turquoise remains plotted on vertical profiles (A) and horizontal profiles (B) throughout the sequence. On vertical profiles, the first long mark along the scales indicates the beginning of the compact mass of commingled cremains (below the compact layer of stones and sediment); the intermediary mark indicates the first discoveries of anatomical connections within the burial; the last long mark indicates the bottom of the grave.

Thompson 2005; Walker et al. 2008) and explored three-dimensional mapping of these alterations. The assemblage was divided in seven layers, each of which comprised one of the observed colors: yellowish, brown-gray, dark-black, blue-gray, chalky-white, yellow-white and turquoise; $\mathrm{Z}$ values of every centroids (measured in the field and reported in the attribute database) were used as a base height to produce three-dimensional scatterplots of cremains colors (FIG. 7).

From the resulting 3D maps of burning intensity, we subsequently modeled the dynamic phenomenon of combustion, smoothing the data. Colors were grouped in several layers of heat intensity, increasing 


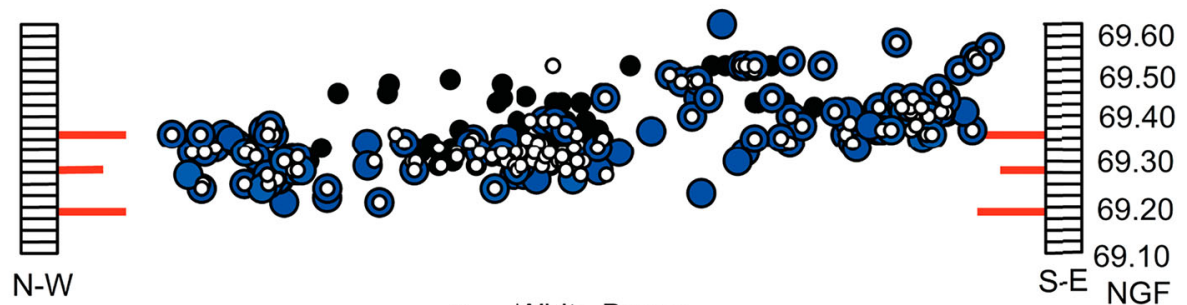

- White Bones

Blue-Grey Bones

- Warped Bones
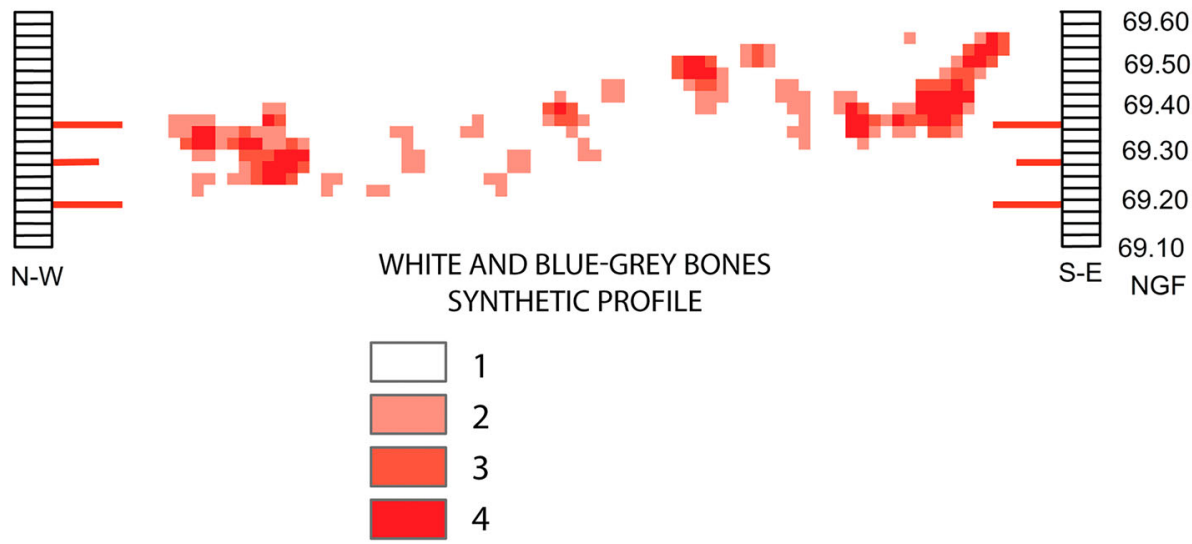

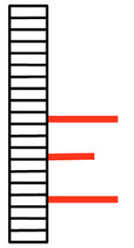

$\mathrm{N}-\mathrm{W}$

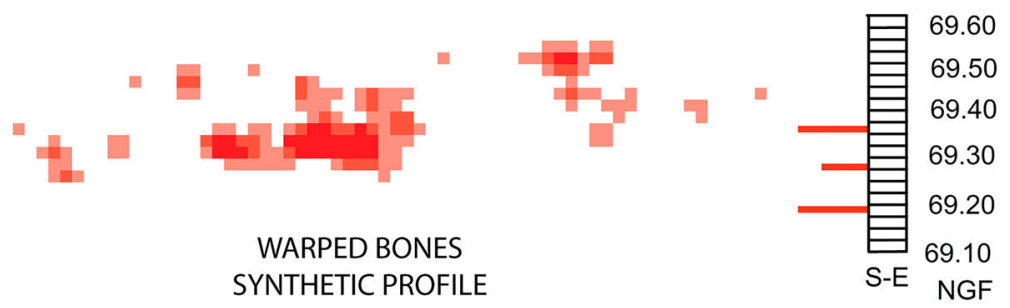

Figure 6 GIS distribution and spatial analyses. Distribution and Kernel density analyses of white, blue-gray and warped bones within the burial; cremains are plotted on synthetic vertical profiles.

from low intensity to high intensity. For each layer of intensity, we interpolated the centroids' $\mathrm{Z}$ values, applying the method of natural neighbors $(0.05 \mathrm{~m}$ grid) to obtain $2 \mathrm{D} \frac{1}{2}$ continuous surfaces of intensity. Then, we overlapped these surfaces of intensity to approximate a continuous model of heat diffusion throughout the burial. We produced two models, varying the markers of intensity. This method implies a homogeneous distribution of the sampled centroids, a condition which is hardly satisfied in such an archaeological sample. Performed in an attempt to explore GIS' potential to analyze a burned and commingled skeletal assemblage, the resulting models should only be considered as dynamic depictions of combustion that strongly rely on our previous interpretations of the archaeological sequence (FIG. 8).

Finally, we compared differential fragmentation throughout the burial sequence to facilitate discussions of the magnitude of human interventions during the fire event. Since the fragmentation of fresh corpses mainly occurs when burning bones are handled (Franchet 1933; Dokládal 1963, 1999; Stiner et al. 1995; Grevin 2002; Warren and Shultz 2002; Schultz et al. 2008; Depierre 2010), we consider that the presence of a high level of fragmentation may indicate a managed combustion while a low level of fragmentation may document a non-managed fire (TABLE 1). Advocated as the best way to assess the level of fragmentation 


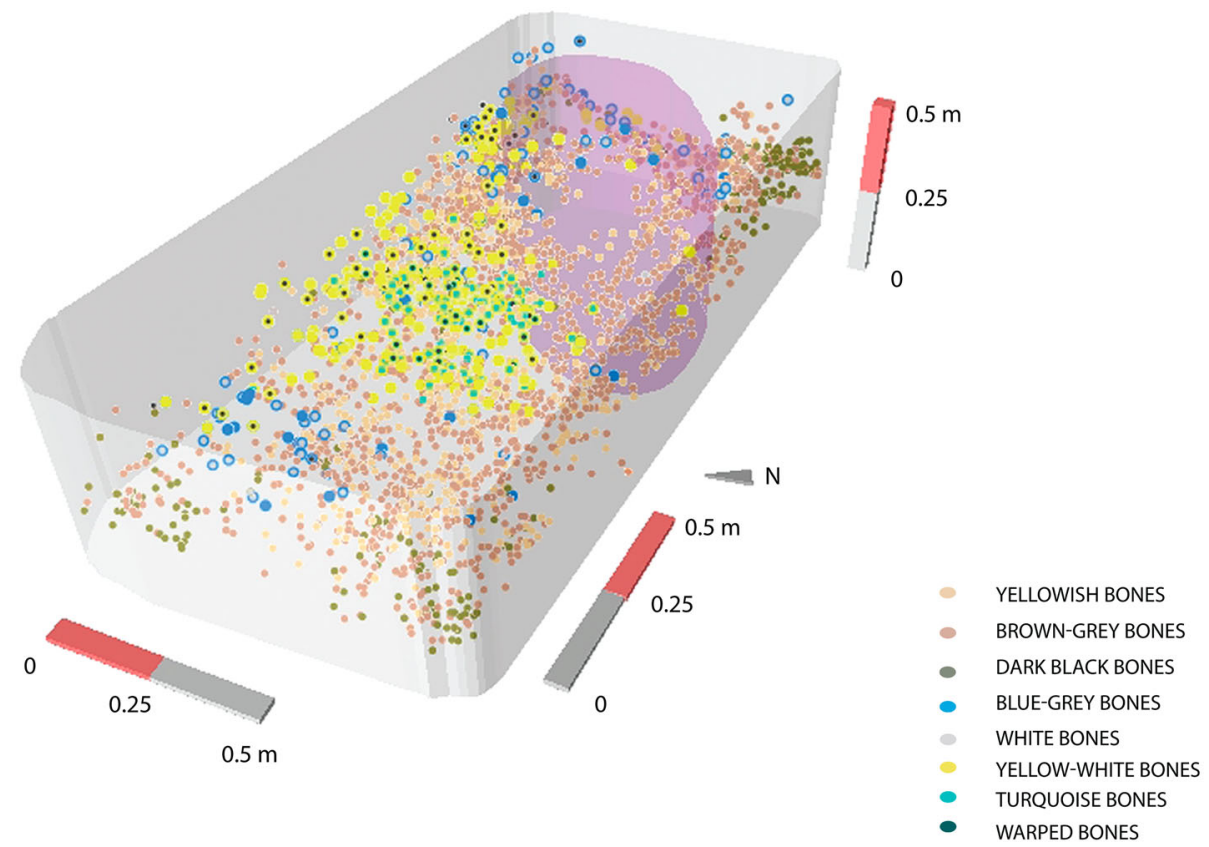

Figure 7 GIS distribution analyses. 3D scatterplot of cremains colors; the gray rectangle represents the wooden structure of the grave; the purple cylinder represents the secondarily disturbed area.

(Duday et al. 2000; Lenorzer 2006), we computed the average weight of identified remains per anatomical parts. Then, we divided the skeletal assemblage into four coherent layers of cremains through simple attributes queries and compared the average weight of identified remains by anatomical parts between the different layers. This method was replicated with the average surface of identified remains
- computed through GIS - in an attempt to optimize the calculation of the index of fragmentation.

\section{Results}

\section{Oxidant and fuel}

Both horizontal and vertical profiles document high concentrations of turquoise, white and yellow-white cremains in the upper part of the assemblage (the
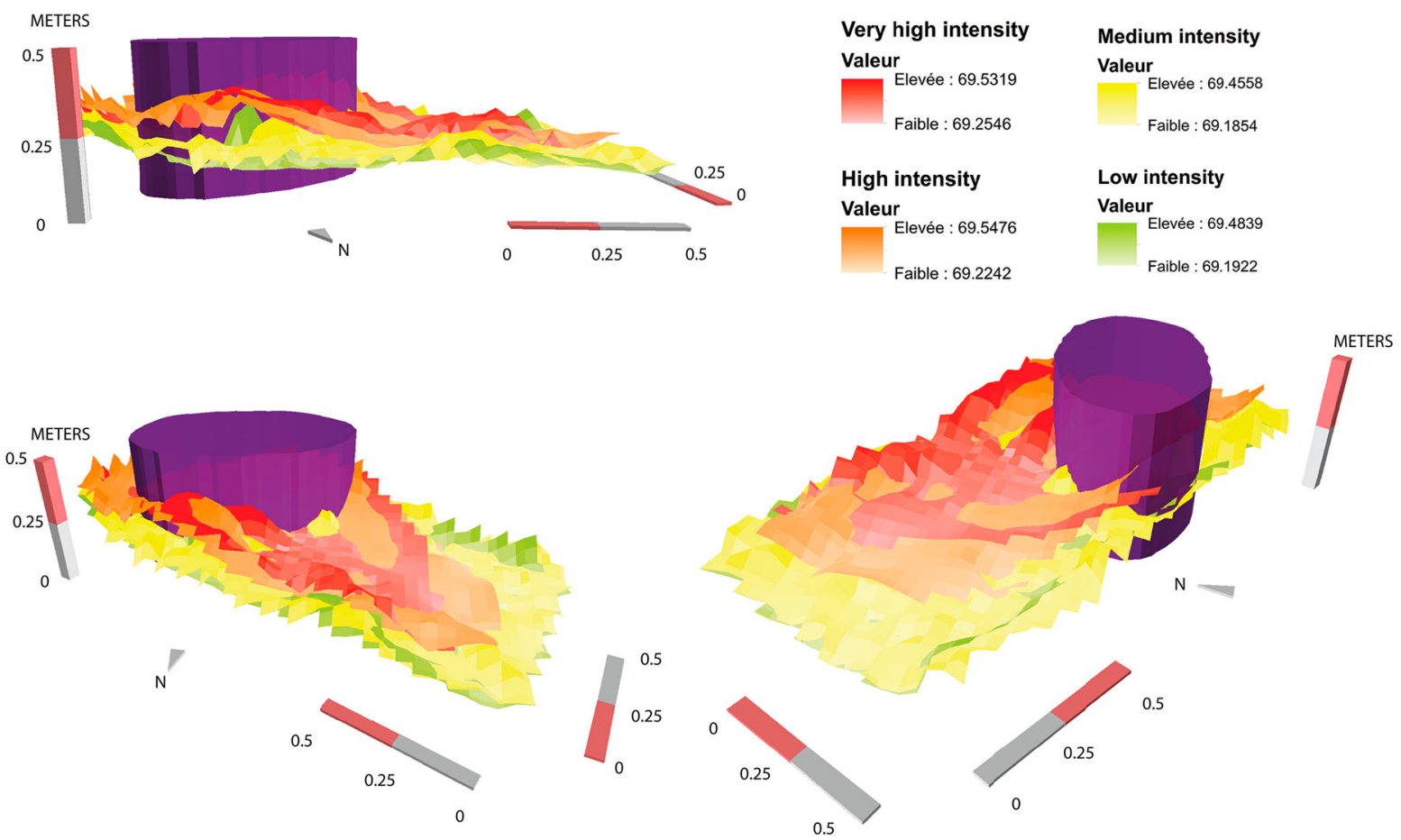

Figure 8 GIS spatial analyses. Second model of combustion: interpolation of cremains colours grouped in increasing layers of intensity; the natural neighbors method with a $0.05 \mathrm{~m}$ grid; the purple cylinder represents the secondarily disturbed area. 
compact mass of commingled bones; between 69.36 69.28 NGF [Nivellement general de la France]) (FIG. 5), while almost none of these markers are distributed in the deeper part of the burial (in the layers of anatomically connected skeletons; below 69.26 m NGF). By contrast, dark black cremains are primarily distributed in the deeper layers (FIG. 4). Given that bone turns white when heated to high temperatures in an oxygen-rich environment and turns to black when burned in reducing conditions (Lisowski 1968; Herrmann 1972; Perinet 1982; Walker et al. 2008), the observed spatial pattern suggests different combustion atmospheres in the upper and deeper levels of the burial.

Gray-blue, white and warped cremains are also primarily concentrated in the upper part of the skeletal assemblage (FIG. 6) above $69.28 \mathrm{~m} \mathrm{NGF}$, although they are in lower densities and more widely-distributed than the previous markers. A wide range of colors, including hues of gray-blue and white, as well as the presence of warping are usually observed during the combustion of bones surrounded by soft tissues, bodily fluids, or bones still containing large amounts of fat and marrow (Baby 1954; Binford 1963; Thurman and Willmore 1980; Buikstra and Swegle 1989; Guillon 1987; Grévin 2002; Nawrocki 2003; Baker Bontrager and Nawrocki 2008; Schultz et al. 2008; Symes et al. 2008; Walker et al. 2008; Depierre 2010). Therefore, results support the hypothesis previously suggested by the examination of cracks and fractures performed on the preliminary subsample: a few fresh corpses may have burned in the upper part of the assemblage. In view of the general low densities of these markers, the fresh corpses were certainly surrounded by numerous dry skeletons.

For a fire to be intense enough to redden the sediment, to crack stones and to produce turquoise stains (i.e., more than $600^{\circ} \mathrm{C}$ [Regert et al. 2006]), there must be efficient fuel within the deposit. The excavations of the 29 postholes surrounding the structure did not provide any evidence for the possible use of posts to feed the fire. Moreover, in the absence of stratigraphic relationships between the surrounding structure and the grave (and the absence of an absolute date for the former), one cannot exclude the possibility that the monument may have been erected after the period of grave utilization. In the absence of remains of charcoal within the assemblage, only human corpses may provide some indication as to a possible fuel source (fats from decaying corpses). Considering that fat is the most efficient fuel in the human body (McKinley 1994; Christensen 2002; Bass and Jantz 2004) and that dry bone cannot feed an intense fire without additional organic input
(Costamagno et al. 1999; Théry-Parisot and Costamagno 2005), the fire was probably partially fed by organic components from human corpses still decaying in the grave. The external input of some raw material that did not leave traces is likely (wood but no remaining charcoal because of the acidic soil, or plant or animal raw material such as fat, dung and marrow). Yet we assume that the presence of a few fresh corpses was necessary to burn the whole assemblage.

Such different heating environments between the upper and deeper burial layers (oxygenated conditions and the probable presence of fresh corpses on the top of the sequence vs. reducing atmosphere of combustion and corpses already skeletonized in the deeper layers) may be explained by the presence of some material (such as a wooden plank?) and/or by the height reached by the sediment within the grave. Stiner and colleagues (1995) demonstrated that the isolation of bones from the heating source and from oxygen availability after burying results in incomplete combustion and in dark colors (Stiner et al. 1995), and we have seen that dark cremains were mainly distributed in the bottom of the deposit. An organic petrology study performed on bones selected at the bottom of the burial sequence suggests that their dark color can be explained by moderate subjection to heat (Thiol et al. 2010). The level reached by sediment may thus have been an impediment for heat diffusion downward. As an additional line of evidence for the presence of a break within the burial sequence, we examined the spatial distribution of small bones throughout the assemblage. Indeed, the decomposition of numerous overlapping bodies should have resulted in the falling of small bones - carpal bones, lateral and medial cuneiform bones, hands and foot phalanges -and their accretion above the already-filled layers. We excluded from this analysis all hands and feet connected anatomically. Interestingly, results indicate several levels of accumulation (FIG. 9): in the bottom of the grave; above the first levels of top-to-tail inhumations; and at the interface between the deeper burial layer and the compacted mass of fragmented bones.

The distributions of small bones and of cremains alterations (colors, warpings and fragmentation) interpreted together with general osteological observations suggest that: at least 13 successive top to tail interments were deposited during a short period of time in a layer that was maybe covered by some material (a wooden plank?) or later filled with sediments (FIG. 1C, 2A) (for presence of overlapping and interweaving bones see Thiol et al. 2010); the upper layer was perhaps more intensely used by the community and to manage such a reduced space, the Neolithic users 

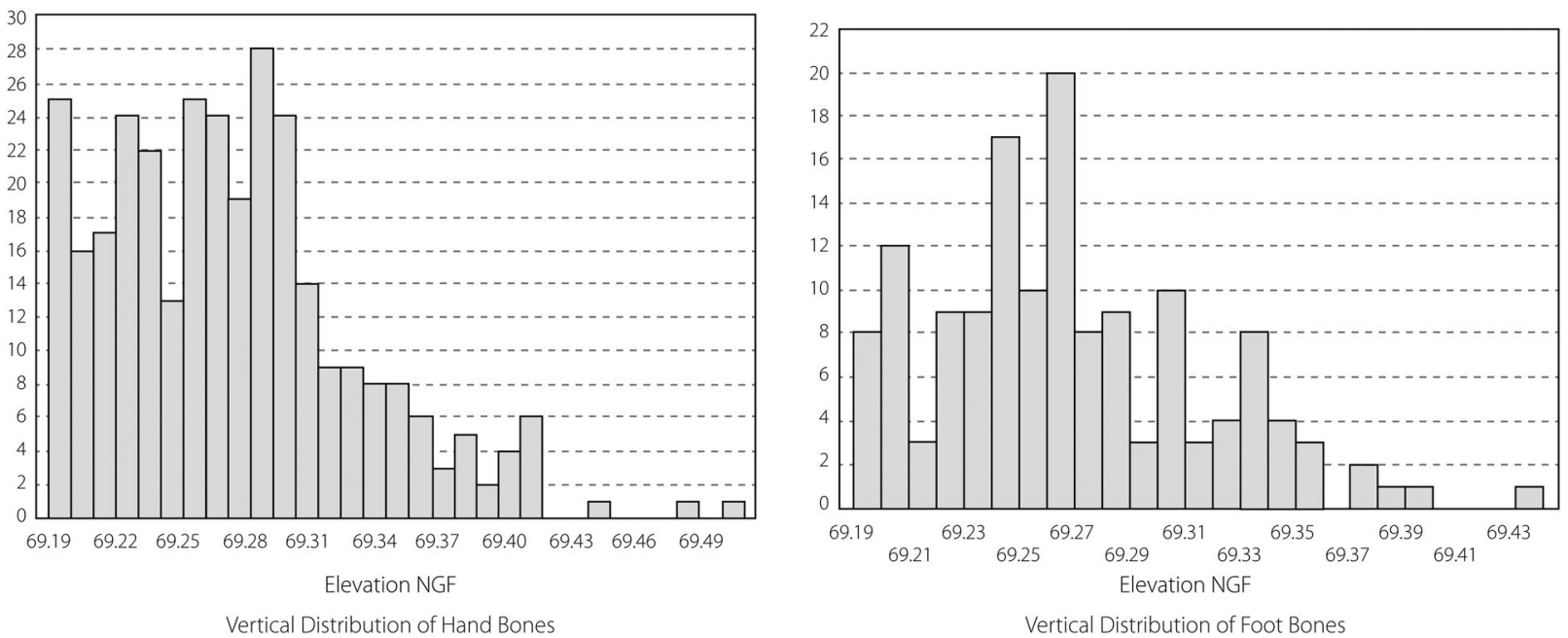

Figure 9 Distribution of hands and foot bones within the burial sequence. The significant layers of accumulation are in the bottom of the grave (69.19-69.20 NGF), above the first levels of top-to-tail inhumations (69.22-69.25 NGF); at the interface between the deeper burial layer and the compacted mass of fragmented bones (69.27-29.30 NGF).

may have processed the corpses; when the fire was ignited, the grave was probably still in use and while the last corpses deposited were perhaps still fresh, the first corpses were apparently already skeletonized.

\section{The dynamic of combustion}

The three-dimensional scatterplots of bone colors accurately reflect the concentric gradient observed during excavations (FIG. 7): turquoise bones are horizontally distributed in the center and in the upper part of the assemblage (above $69.28 \mathrm{~m} \mathrm{NGF)} \mathrm{and} \mathrm{sys-}$ tematically associated with yellow-white cremains which are more widely distributed. These alterations usually occur around $600-800^{\circ} \mathrm{C}$ when burned bones reach the stage of inversion (Shipman et al. 1984; Susini 1988; Mayne Correia 1997); gray-blue cremains are almost systematically associated with white

Table 3 Increasing layers of burning intensity defined by grouping cremains colors according to published studies performed on cremated bones and to the observed distribution of cremains in the assemblage of La Truie Pendue (FIG. 7); these layers are used to model the dynamic of combustion of the bone assemblage (FIG. 8).

\begin{tabular}{|c|c|c|}
\hline $\begin{array}{l}\text { Burning } \\
\text { intensity }\end{array}$ & Grouping 1 & Grouping 2 \\
\hline Very strong & $\begin{array}{l}\text { Yellowish, turquoise, } \\
\text { warped cremains }\end{array}$ & $\begin{array}{l}\text { Yellowish, turquoise, } \\
\text { warped cremains }\end{array}$ \\
\hline $\begin{array}{l}\text { Medium - } \\
\text { Strong }\end{array}$ & Gray-blue and white & Gray-blue and white \\
\hline $\begin{array}{l}\text { Medium - } \\
\text { Low * }^{*}\end{array}$ & - & Brown gray \\
\hline Low * & $\begin{array}{l}\text { Brown gray and dark } \\
\text { black }\end{array}$ & Dark black \\
\hline
\end{tabular}

* Since gray colors remain when bones are burned from quite low to high temperatures $\left(200-700^{\circ} \mathrm{C}\right)$ and given the broad distribution of brown-gray cremains in the assemblage, we decided to propose two different models of combustion, grouping brown-gray cremains into slightly different layers of heating intensity. cremains. Their distribution is wider than the previous markers. These colorations may occur when fresh corpses are burned around $300-700^{\circ} \mathrm{C}$ (Shipman et al. 1984; Susini 1988; Mayne Correia 1997); dark black cremains are also partially associated with brown-gray cremains, but are more concentrated in the corners of the deposit. This dark color is typical of lower temperatures of combustion, around 250$500^{\circ} \mathrm{C}$ (Shipman et al. 1984; Susini 1988; Mayne Correia 1997); yellowish cremains are widely distributed but are generally found below turquoise, yellowwhite, white and gray-blue markers (below $69.30 \mathrm{~m}$ NGF). From these observations, we grouped bone alterations in several increasing layers of burning intensity and smoothed the data in order to propose two models of combustion of the bone assemblage (TABLE 3) (FIG. 8).

The resulting models both depict the same physical dynamic: a single hearth, located on the top of the burial sequence and shifted toward the east, first

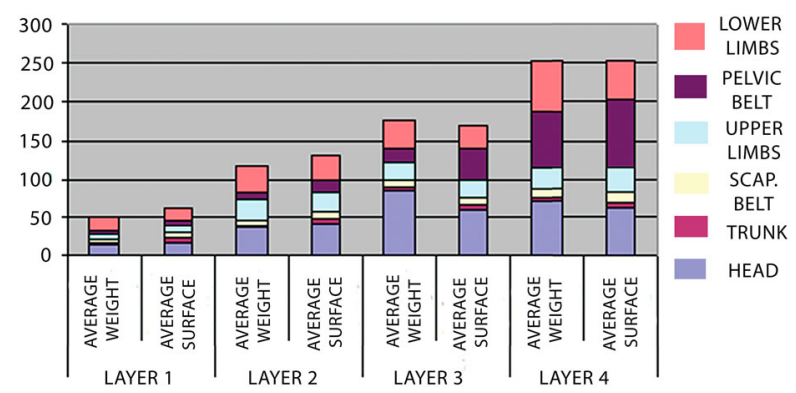

Figure 10 Weight and surface of an average bone through the different layers of the burial sequence: at the discovery of the skeletal assemblage (layer 1); in the compact mass of commingled and fragmented cremains (layer 2); among the first anatomical connections (layer 3); among the anatomically-connected skeletons of the deeper part of the grave (layer 4). 
diffused the heat westward following a general eastwest dip of the remains. Temperatures reached at least $600-800^{\circ} \mathrm{C}$ in the center of the hearth. The deeper part of the grave and the structure corners burned at a lower intensity, maybe in a more reduced heating environment. Compared to traditional maps, such three-dimensional models contribute to a dynamic interpretation of the depositional history of archaeological cremains.

\section{Towards an assessment of human gestures}

The analysis of the surfaces and the weights of cremains both document strong fragmentation in the upper part of the burial (FIG. 10). The sizes of an average remain is almost four times higher when it is located in the deeper funerary layers than when it is located in the top of the burial sequence. Similarly, an average remain from the deeper layers is almost two times larger and heavier than an average remain from the upper part of the sequence. Considering that the fragmentation of fresh corpses mainly occurs when burning bones are handled (Franchet 1933; Dokládal 1963, 1999; Stiner et al. 1995; Grévin 2002; Schultz et al. 2008; Depierre 2010) and that the sizes of cremains widely vary according to the processing method (Warren and Schultz 2002; Schultz et al. 2008), analyzing the different levels of fragmentation provides a relevant way to examine the management of the cremation (Duday et al. 2000; Lenorzer 2006). Thus, we hypothesize that an intentional fire was ignited on the top of the burial sequence and managed with pokers (or similar tools), or possibly pounded/trampled to be extinguished. The deeper layers remained more protected: whether because they were already filled, under some material within the burial sequence, or simply because the first deposited corpses were less accessible (given the number of overlying corpses). Whether the fire was managed with some tools or the deposit was pounded/trampled, in both cases it had the effect of processing the corpses and reducing bodies to small pieces. However, once the fire reached high temperatures, displacement of the cremains was limited since the color gradient was preserved. Shortly after the fire, a substantial layer of sediment mixed with stones was deposited just above the hearth, preserving the picture of the fire episode.

These results highlight the relevance of including an examination of surfaces and weight of remains when assessing fragmentation. Since GIS enables an automatic computation of remains' surfaces, new taphonomic approaches to analyzing highly fragmented skeletal assemblages are opened. This preliminary approach to the study of fragmentation should be refined in the future, both vertically and horizontally within the assemblage. Paired with bone dispersion analyses (Duday et al. 2000), GIS could allow for the possibility of computing the orientation and the magnitude of fragment displacements, allowing a better understanding of the nature of human gestures executed in the grave.

\section{Discussion}

Although the altered nature of the burned assemblage has made the reconstruction of funerary gestures difficult, our interpretations were aided by examining the fire from a bioarchaeological perspective (Weitzel and McKenzie 2008). Through spatial analyses of the physical alterations of the cremains, we reconstructed the fire episode as an integral part of the grave's history. The successive deposition of several corpses (at least 13 individuals) took place within a wooden structure in a first layer of inhumation; after some time (perhaps a break in the burial sequence?), many corpses were successively deposited and bodies within the funerary space were probably manipulated. Shortly after deposition of the last corpses in an inhumation layer crowded by commingled skeletons, a fire was intentionally ignited on top of the burial sequence. The fire was managed and finally covered by the deposition of a substantial layer of sediment and stones. The fire episode thus occurred late in the grave's history, which leads to questions concerning the role assigned to fire by the Neolithic community using the grave.

Although burning fresh corpses, or sometimes skeletons, was a known practice during the Mesolithic, inhumation is recognized as the dominant practice during the Neolithic in Europe, with the exception of a few regions such as Ireland where cremation remained a frequent practice in chambered tombs. In France, the phenomenon of collective graves became widespread from the second half of the 5th millenium until the end of the 3rd millenium в.c. (Late to Final Neolithic periods); these structures had many shapes (e.g., simple pits, wooden or stone coffers, hypogea, dolmens, gallery graves, tumuli), but all with the same principle of inhumation: a successive deposition of several corpses, over decades or centuries. The structure was designed by the community to receive the deposition of numerous corpses (dozens and sometimes hundreds of bodies were deposited), and to last a long period of time, prompting the community to manage the funerary space in different ways, including using various means to process corpses (Leclerc 1996; Chambon 2003). Among an outstanding corpus of several thousand collective graves listed for the Late Neolithic period in France (6000 Neolithic structures are referred to as a collective graves in the available archaeological literature from the 19th century to the present according to Chambon [2003]), only a few have yielded evidence of fire or cremains; 101 are listed by E. Gatto (Gatto 2004, 2007). Among 107 collective graves for which the archaeological 
documentation is considered reliable enough, P. Chambon presented only five examples with cremated bones, emphasizing the fact that "in collective graves, the funerary practice relies on the principle of the inhumation," cremation appearing only as a subsidiary element (Chambon 2003: 105). The main concentration of cremains found in Neolithic graves is located in the Paris Basin and in the southeastern part of France (Gatto 2004, 2007). Re-analyses of some burned bone assemblages have enabled researchers to distinguish different types of cremain deposits within collective graves (Gatto 2007): primary deposits of cremated remains, where the fire occurred at the final location where bodies were deposited and which can include several fire events (e.g., at La Grotte du Gardon, Ain [Gatto 2003]); primary deposits of cremated remains found alternately with unburned corpses (Tertre 3 of Peyrolebade, Aveyron [Gatto 2003]); secondary deposits of cremated remains, implying that the process of cremation occurred on a combustion area (a convincing example for a Neolithic pyre has been recently given by DesbrosseDegobretière and colleagues [2010] on the site of Buchère, Aube) and was followed by the burial of cremains in another location (e.g., dolmen II of San Sebastian, Var [Sauzade 1988]).

The regional distribution of primary versus secondary cremations partially overlaps and barely fits with defined archaeological cultures (Gatto 2007), making correlations between the observed diversity in patterns of cremation and the affiliation to specific groups difficult. Actually, the variability in patterns of cremation within Late Neolithic funerary contexts is not unexpected: if inhumation is the standard procedure, it can include many modalities within collective graves such as corpse displacement, or the reduction of bodies through skull or long bone removals (Leclerc 1996). Therefore, the observed diversity in the nature of cremains deposits fits within the general category of collective burials (Gatto 2003).

In all aforementioned cases, the use of fire always aims at processing corpses, which is clearly different from the case at La Truie Pendue, where the fire burned the whole structure and not only a few corpses. The whole process of burning should be understood as a secondary process which occurred as a single event and in the same place, and was thus distinct from secondary depositions. The whole grave was burned during a final event, followed by the deposition of sediment and stones that closed access to the dead. Thus, the fire event appears to be the first step of a procedure that sealed the grave; it signaled the end of the grave's history. This fire event can be related to the phenomenon of condemnation of collective graves mentioned by numerous authors (the process of condemnation being understood as the act of creating a sealing layer, and/or the systematic destruction of the monumental architecture of the grave (Masset 2002; Chambon 2003; Masset et al. 2013). Such procedures to ensure a permanent closure of the collective graves were almost always systematic during the Late Neolithic: simple deposition of stones (e.g. Bazochesur-Vesle, Aisne [Leclerc 1995]), of megaliths (e.g., at Méréaucourt, Somme [Guy and Masset 1991; Masset et al. 2013]), or whole destruction of the monumental architecture of the grave (e.g., Changé, Eure-etLoire [Jagu 1996]; Villedubert, Aude [Duday 1995]). In several cases, fire seems to have been used in this sealing procedure. E. Gatto recorded 11 cases where fire seems to have closed the funerary sequence. Eight of these cases are located in the Paris Basin (Gatto 2004). Only a few cases are well-described enough in the archaeological literature to be certainly assigned to a process of condemnation of the grave.

In the Paris Basin, at least five collective graves shared striking similarities with La Truie Pendue. Dated to the transition between the 4th and the 3rd millennium B.C., a gallery grave discovered in Lacroix Saint-Ouen (Oise) yielded numerous indications of intense heating (Le Goff et al. 1995, 2002; Billand et al. 1995a, 1995b; Guillot et al. 1996; Le Goff 1998). The sediment was reddened, temperatures of about $500-850^{\circ} \mathrm{C}$ turned architectural limestone slabs into whitewash, and charcoal remains were discovered in a large area within the deposit (Masset 2002). Although the examination of anatomical connections suggested that most of the corpses were already decomposed when the fire burned the assemblage (Le Goff et al. 2002), analyses of physical alterations suggested the presence of a few fresh corpses among dry skeletons (Masset 2002). Only $700 \mathrm{~m}$ away from this deposit (at Longueil-Saint-Marie, Oise) two contemporaneous collective gravessimilar by shape and architecture - also yielded evidence for an intense fire on the top of the burial sequences (Billand et al. 1995a; Le Goff et al. 2002). The excavators of Le crématoire de la Hoguette (3800-2550 B.c.) and Calvados, excavated a passage tomb made of wood and limestone slabs, with a hearth "extended over the whole deposit" which covered an assemblage of "extensively cracked and warped bones" (Caillaud and Lagnel 1972: 189). For some cases, such as Maison-Rouge (Loiret) (Van Viet 1980) or Reichsett (Alsace) (Blaizot 2005), it is difficult to unravel the chronology or the nature of the fire event (last event? accidental fire or cremation on purpose?). All these graves being made of wood, we may wonder whether there might be a correlation between this architectural material and the final fire episode (Gatto 2003). Was the wood material chosen in expectation of fire or was the fire ignited to seal the burial because of its wooden architecture? 
It is sometimes quite clear that fire was used because of its technical abilities to destroy architectural elements. At La Chaussée-Tirancourt (Somme), fire helped to fracture a sandstone orthostat (Masset 1995), which was also probably the case at the site of Chiozé (Marne) (Morel 1869; Masset 2002). The use of fire was then probably motivated by historical circumstances, such as the arrival of a new group that attempted to assert its territorial, social or symbolic position, destroying the tombs of ancestors as former landmarks of the identity of the predecessors. The destruction of former graves when a new group is settling, a new social order appears or a different ideology is developing is a known phenomenon during the Neolithic and Chalcolithic periods. For instance, at Villedubert (Aude), after the complete destruction of the orthostats belonging to a Late Neolithic collective grave, a new Chalcolithic collective grave was built above the ruins of the former (Duday 1995). This scenario cannot be dismissed for $\mathrm{La}$ Truie Pendue. However, the fact that the grave was included in a quadrangular building that did not yield traces of destruction by fire makes it less plausible. Unfortunately, it is unknown whether the building was contemporaneous or built after grave use. In the former case, the use of fire to simply destroy the grave and not the superstructure is surprising, and the latter case would suggest a way to perpetuate the memory of the grave despite its destruction. Interestingly, on the site, a similar building also included several burials (simple inhumations) and one pit containing some burned remains (cremains of at least one individual) (Thiol et al. 2010). The inclusion of burials within quadrangular buildings, suggests the presence of specific houses for the dead (cf. Online Supplement; Lecornue et al. 2009). Although the architecture of the quadrangular structure resembles the shape of Danubian houses of the Early to Middle Neolithic in the Paris Basin, the association of this architecture with funerary deposits also is reminiscent of the Middle Neolithic "Passy type" cemeteries where some of the dead were deposited within elongated structures (albeit only a few individuals were buried in these giant enclosures during the Middle Neolithic, contrary to the Late Neolithic collective deposits).

The presence on the site of another pit which contained cremains (a secondary deposit of cremated remains) also suggests that the use of fire was probably not intended only for technical purposes; however, no material element allowed us to assign for certain this finding to the Late Neolithic. It is worth mentioning that, in France, most cases where fire was used during grave condemnation procedures are in the Paris Basin and/or in southeastern France, where the presence of Neolithic cremations is also the best documented. Close to Passy-Véron, Late Neolithic secondary cremations were also found in pits at the site of Monéteau sur Macherin (Yonne) and within a wooden structure at Chény (Yonne) (Gatto 2003). In the context where cremation existed as a subsidiary element to the standard practice of inhumation, one can suggest that including fire in a procedure that closed the collective burial may pertain to a specific funerary behavior - a sort of middle practice between collective inhumation and the practice of cremation. Although the use of fire in procedures of condemnation clearly aims at destroying the whole grave and thereby differs from cremation, yet the similarities among several contemporaneous burned collective graves in the Paris Basin (La Truie Pendue, La Croix Saint Ouen, the two cases at Longueil-Saint-Marie, La Hoguette, and Maison-Rouge) suggest that symbolic value was certainly assigned to the element of fire. Also, one should not underestimate the spectacular impression that the dramatic incineration of a collective grave may have created, especially if the fire occurred in a closed structure, as may have been the case at La Truie Pendue where there is evidence of a quadrangular building (Online Supplement).

We considered the possibility that a few fresh corpses may have fed the intense fire; it is possible that just after the last deposits when the grave was deemed full/completed by the community, fire was used as a means to achieve the decomposition of all corpses (and skeletons) together and to simultaneously destroy the funerary structure. Indeed, Neolithic collective graves should not only be understood as simple places where the dead were deposited but also as rooms used to artificially process the decomposition of corpses and manage the crowded burial space. The dead bodies were handled, reduced, and reorganized (skulls were often deposited along the walls of the grave, long bones grouped in fagots) in a process that achieved little-by-little their de-individualization; fire may have contributed towards this process of personal oblivion. In some cases, such as at La Croix des Cosaques (Marne) (Schmitt 1892) and at Hérouval (Oise) (Masset 1992), it has been suggested that an intense fire burned one of the inhumation layers, but was further followed by an additional deposition of bodies. In cases such as this, fire may have been a technical means to manage the space, a tool to process corpses and maybe also in a symbolic way to purify the place, to achieve the de-individualization of the bodies before depositing the latest dead. Similarly, in cases of condemnation, fire probably played a versatile role as both a purifying element and a destructive tool (Thomas 1980), burning simultaneously all the dead and destroying their related spaces, thereby closing the burial once and for all. In many societies, the different steps of the funeral process are interrelated with the various stages of the decaying corpse (Hertz 
1907). At La Truie Pendue, after the final deposition of the last corpses in a crowded burial space, the prompt reduction of many corpses and skeletons into cremains could have been the shortest way to symbolize the actual end of the collective mourning period. Burning simultaneously all the dead and their related space through an intense fire was perhaps a way for the community to finally achieve the passage (sensu Van Gennep 1960) from individuals to minerals and to signal the transition from the crowded grave of the ancestors to the foundation of a new place for the dead. And yet, if the quadrangular structure remained after the condemnation of the grave, the place probably kept an important symbolic value long after the fire episode.

Dated to the second half of the 4th millenium в.с., the collective burial at La Truie Pendue is one of the oldest examples of this procedure of a condemnation of a grave, at a time when the use of fire in funerary contexts became widespread in Western Europe. Out of the Paris Basin, several important collective funerary deposits have also been intensely disturbed by similar fires. In southeastern France, the top sequences of the Hypogeum of Roaix (Vaucluse) (Courtin 1974) and of the dolmen of Dignas (Lauzère) (Fages 1987) have clearly been destroyed by fire. Discovered in 2013, the collective grave of La Cavalade (Hérault) has been interpreted as having a "deliberate layer of condemnation with fire" (Tchérémissinoff and Leal 2014). In Germany, the collective burial of Wandersleben is similar in all respects to Lacroix Saint-Ouen (Müller and Stahlhofen 1981). In Britain and Ireland, among many examples of long borrows disturbed by fire, the most famous may be the site of Haddenham (Evans and Hodder 2006); Kinnes mentions four graves with traces of fire on architectural elements and seven graves where it is clear that the whole structure burned (Kinnes 1992). In the cases of long borrows, as well as in Wandersleben, the sealing layer became so important that it created a tumulus, shaping the landscape. In Spain, the sites of La Peña de la Abuela, and of El Miradero are famous cases of the condemnation with fire, but numerous other examples are presented by Rojo Guerra and Kunst (1999).

Along with this specific use of fire, the cremation of multiple individuals then became more frequent during the Final Neolithic and the Chalcolithic periods. For instance in Portugal the site of Olival de Pega yielded an area of mass cremations (Gonçalves 1999), and the site of Perdigoes has been considered as a "collective secondary cremation context" with a minimum number of individuals estimated at 150 (Valera et al. 2014: 46). One could thus hypothesize that a change concerning the role of fire in funerary contexts occurred somewhere between the Late
Neolithic and the Final Neolithic-Chalcolithic periods. After being a means to symbolically and technically close the grave, the use of fire eventually evolved only toward processing corpses, being finally included a priori in the funerary process, and no longer occurring final stage of the grave's history.

\section{Conclusions}

Discovered in close proximity to the Middle Neolithic monumental cemeteries of Passy (Yonne), the Late Neolithic collective grave of La Truie Pendue was found within a wooden superstructure and yielded the burned remains of at least 65 individuals. The cremains show myriad physical alterations as well as a unique gradient of colors, an actual snapshot of a fire lighted by a prehistoric community. In mapping the cremains' physical alterations, we inferred the original conditions of combustion and reconstructed the course of the fire within the funerary sequence, leading to questions about the reasons for this funerary behavior.

This study demonstrates the value of using GIS and spatial analyses to optimize taphonomic analyses of widely fragmented and commingled assemblages. Although time-intensive, this image-based approach provides a way to unravel the complex processes responsible for the formation of highly altered archaeological deposits. Beyond the management and visualization of large quantities of fragmented remains, the possibility of comparing spatial and attribute data allows for new bioarchaeological analyses and interpretations. Multi-dimensional views and spatial statistical tools enable circumvention of problems imposed by artificial limits that usually divide archaeological analyses into grids and provide the means for dynamic interpretations of remains' depositional and post-depositional history. This dynamic approach particularly suits the study of Neolithic collective graves where corpses are deposited both horizontally and vertically (in a limited space and for a long time); it opens avenues of future research to decipher complex funerary behaviors.

Results also confirm the value of using heating signatures as taphonomic tools, provided that thorough contextual analyses are carried out. Our interpretations suggest that an intentional fire was ignited during a late stage of the grave's history, shortly after the deposition of the last corpses in the upper part of the burial. After the burning of the whole assemblage, the fire was extinguished by the deposition of a substantial layer of blocks and sediment which closed the access to the grave. Although the role of fire was not to burn corpses (differing from the practice of cremation) but to destroy the whole grave, the comparison with similar and contemporaneous deposits from the Paris Basin suggests that a symbolic value was 
probably assigned to the element of fire. After the last depositions of corpses, to burn simultaneously the whole gravesite and all the dead together may have been a way to purify the place and to signal the transition from the crowded grave of the ancestors to the foundation of a new place for the dead. Inserted in a quadrangular structure, the place probably had a symbolic value for a long time. Similar cases of burned funerary deposits in western Europe suggest that the procedure to symbolically seal collective graves with fire was not uncommon during the Late Neolithic. During the end of the Late Neolithic and the Final Neolithic-Chalcolithic periods, it seems that the use of fire in funerary rites served mainly to process the corpses and was finally no longer the last stage of the grave's history.

\section{Acknowledgement}

The authors are grateful to Rachael Leahy (Ph.D. Ohio State University) for the review of the English language.

Camille de Becdelievre (M.A. 2011, University of Bordeaux, France) is a Ph.D. Candidate in the Department of Archaeology, University of Belgrade, Serbia. He is interested in the bioarchaeology of Late European prehistory (Mesolithic, Neolithic and Bronze Age).

Sandrine Thiol (Ph.D. 2002, University of Bordeaux, France) is Director of Excavations and Research, Institut national de recherches archéologiques préventives, France. Her interests include rescue archaeology and the funerary practices from Neolithic to Antiquity in Northern France.

Laure Saligny (M.A. 1999, University of Bourgogne, France) is interested in spatial archaeology, spatio-temporal modeling and analysis, and spatial statistics.

Ludovic Granjon (M.A. 2005, Institut National Polytechnique de Toulouse, France) is interested in GIS development and analysis, spatio-temporal modeling and analysis, software and webmapping development, and database modeling.

Stéphane Rottier (Ph.D. 2003, Université de Bourgogne, France) is interested in funerary practices in Late European prehistory (Neolithic, Bronze and Iron Age).

\section{ORCiD}

Ludovic Granjon (10) http://orcid.org/0000-0002-05765497

\section{Supplemental data}

Supplemental data for this article can be accessed here at doi:10.1080/00934690.2016.1219209.

\section{References}

Baby, R. S. 1954. "Hopewell Cremation Practices," Papers in Archaeology 1: 1-7.

Bass, W. M., and R. L. Jantz. 2004. "Cremation Weights in East Tennessee,” Journal of Forensic Sciences 49(5): 901-904.

Baker Bontrager, A., and S. P. Nawrocki. 2008. "Taphonomic Analysis of Human Cremains From The Fox Hollow Farm Serial Homicide Site," in C. W. Schmidt and S. A. Symes, eds., The Analysis of Burned Human Remains. London: Academic Press, 211-226.

Billand, G., H. Guillot, and I. Le Goff. 1995a. "Lacroix-SaintOuen, Le Prieuré (Oise)," in C. Masset and P. Soulier, eds., Allées couvertes et autres monuments funéraires du Néolithique dans la France $d u$ nord-ouest, Allées sans retour. Paris: Editions Errance, 169-170.

Billand, G., H. Guillot, I. Le Goff, F. Malrain, and E. Pinard. 1995b. "Trois structures funéraires collectives dans la moyenne vallée de l'Oise. Acte du XIXe colloque interrégional sur le Néolithique," Revue archéologique de Picardie 9: 36-37.

Binford L. R. 1963. "An Analysis of Cremation From Three Michigan Sites," Wisconsin Archaeologist 44: 98-110.

Blaizot, F. 2005. "Contribution à la connaissance des modes de dislocation et de destruction du squelette pendant la crémation: l'apport du bûcher funéraire en fosse du Néolithique final à Reichstett-Mundolsheim (Bas-Rhin)," Bulletins et mémoires de la Société d'Anthropologie de Paris. 17(1-2): 13-35.

Bonucci, E., and G. Graziani 1975. "Comparative Thermogravimetric, X-Ray Diffraction and Electron Microscope Investigations of Burnt Bones from Recent, Ancient and Prehistoric Age," Atti della R. Accademia dei Lincei. Rendiconti della Classe di scienzefisiche, matematiche e naturali, serie 8. 59(5): 517-532.

Buikstra J. E., and M. Swegle. 1989. "Bone Modification Due To Burning: Experimental Evidence," in R. Bonnichsen and M. H. Sorg, eds., Bone modification. Orono: Institute for Quarternary Studies, University of Maine, 247-258.

Burrough, P. A., and R. A. McDonnell. 1998. Principles Of Geographical Information Systems. Oxford: Oxford University Press.

Caillaud, R., and E. Lagnel. 1972. "Le cairn et le crématoire néolithiques de la Hoguette à Fontenay-le-Marmion," Gallia Préhistoire 15(1): 137-197.

Carre, H. 1985. Sauvetage programmé de Passy 89 La Sablonnière, campagne 1985. Sens: S.R.A. de Bourgogne.

Chambon, P. 2003. Les morts dans les sépultures néolithiques en France: du cadavre aux restes ultimes. XXVe supplément à Gallia-Préhistoire. Paris: Editions du CNRS.

Christensen, M. A. 2002. "Experiments In The Combustibility Of The Human Body," Journal Of Forensic Sciences. 47(3): 466-470.

Civjan, S., W. J. Selting, L. B. de Simon, G. C. Battistone, and M. F. Grower. 1971. "Characterization of Osseous Tissues by Thermogravimetric and Physical Techniques," Journal of Dental Research 51: 539-542.

Costamagno, S., C. Griggo, and V. Mourre. 1999. "Approche expérimentale d'un problème taphonomique: utilisation de combustible osseux au Paléolithique," Préhistoire européenne 13: $167-194$

Courtin, J. 1974. "Le Néolithique de la Provence," Mémoire de la Société Préhistorique Française 11. Paris: Lincksieck.

de Becdelievre, C., S. Thiol, F. Santos, and S. Rottier. 2015. "From Fire-Induced Alterations On Human Bones To The Original Circumstances of The Fire: An Integrated Approach Of Human Cremains Drawn From A Neolithic Collective Burial," Journal of Archaeological Science: Reports 4: 210-225.

Dehaan, J. D. 2008. "Fire and Bodies," in C. W. Schmidt and S. A. Symes, eds., The Analysis of Burned Human Remains. London: Academic Press, 1-14.

Depierre, G. 2010. Des crémations en milieu à haute technologie aux incinérations du passé. Apports méthodologiques et réalités archéologiques. Unpublished Ph.D. dissertation, Université de Bourgogne, Dijon.

Depierre, G., M. Jacquemin, F. Muller, S. Collet, and C. Mordant. 1997. "La nécropole des'Prés Pendus' sur les communes de Passy et de Véron (Yonne): un complexe funéraire du Bronze final I-IIa," Revue Archéologique de l'Est 48: 3-50.

Desbat, A., S. Rottier, H. Coqueugniot, and S. Thiol. 2011. "Le dénombrement des sujets immatures dans les sépultures 
collectives: l'exemple néolithique de La Truie Pendue (Passy, Yonne)," Bulletins et mémoires de la Société d'anthropologie de Paris 24(3-4): 152-166.

Desbrosse-Degobertière, S., V. Riquier, J. Wattez, F. LangryFrançois, and J. Wiethold. 2010. "Un cas de crémation au Néolithique récent. Le bucher de Buchères (Aube)," in C. Billard and M. Legris, eds., Premiers Néolithiques de l'Ouest. Cultures, réseaux, échanges des premières sociétés néolithiques à leur expansion. Rennes: Presses Universitaires de Rennes, $441-452$.

Devlin, J. B., and N. P. Hermann. 2008. "Bone Color As An Interpretive Tool of The Depositional History Of Archaeological Cremains," in C. W. Schmidt and S. A. Symes, eds., The Analysis of Burned Human Remains. London: Academic Press, 109-128.

Dokládal, M. 1963. "Ein Beitrag zur Morphologie verbrannter Menschenknochen," Anthropos 15(7): 29-38.

Dokládal, M. 1999. Morfologie spálených kostí. Sborník prací Lékařské fakulty v Brně. Opuscula anthropologica. Brno: V Brně, Masarykova univerzita.

Duday, H. 1995. "Le dolmen des pérrière à Villedubert Aude," Préactes du colloque de Cérgy Pontoise Monumentalisme Funéraire et sépultures collectives. Cergy-Pontoise: Conseil Général du Val d'Oise, Service Départemental d'Archéologie, $40-42$.

Duday, H. 2009. "The Archaeology Of The Dead: Lectures In Archaeothanatology," Oxford: Oxbow Books.

Duday, H., G. Depierre, and T. Janin. 2000. "Validation des paramètres de quantification, protocoles et stratégies dans l'étude anthropologique des sépultures secondaires à incinération. L'exemple des nécropoles protohistoriques du Midi de la France," in B. Dedet, P. Gruat, G. Marchand, M. Py and M. Schwaller, eds., Archéologie de la Mort, Archéologie de la Tombe au Premier Âge du Fer. Actes du XXIe Colloque International de l'Association pour l'Étude de l'Âge du Fer, Conques-Montrozier. Lattes: Monographies d'Archéologie Méditerranéenne, 5-29.

Evans, C., and I. Hodder. 2006. A Woodland Archaeology: Neolithic Sites at Haddenham. Cambridge: McDonald Institute for Archaeological Research.

Fages, G. 1987. "Le tumulus de Dignas, Commune de SainteEnimie (Lozère)," in H. Duday and C. Masset, eds., Anthropologie physique et archéologie: méthodes d'étude des sépultures. Actes du colloque de Toulouse $(4,5$ et 6 novembre 1982). Paris: Edition du CNRS, 367-377.

Franchet, L. 1933. "La coloration des os dans le sol. Le bouillage des cadavres au Moyen-âge. L'incinération et ses phénomènes," Revue Scientifique 15: 483-495.

Gallotti, R., A. Mohib, M. El Graoui, F. Zohra Sbihi-Aloui, and J. P. Reynal. 2011. "GIS and Intra-Site Spatial Analyses: An Integrated Approach for Recording and Analyzing the Fossil Deposits at Casablanca Prehistoric Sites (Morocco)," Journal of Geographic Information System 3: 373-381.

Gatto, E. 2003. La place de la crémation dans le traitement des défunts à la fin du Néolithique en France. Outils méthodologiques et études de sites. Unpublished Ph.D. dissertation, Université de Bordeaux I, Bordeaux.

Gatto, E. 2004. "La place de la crémation dans le traitement des défunts à la fin du Néolithique en France," in I. Jadin and A Hauzer, eds., Le Néolithique au Proche-Orient et en Europe, Actes du XIVe congrès UISPP, Université de Liège, Belgique, 2-8 septembre 2001, Section 9. Oxford: BAR, 163-170.

Gatto, E. 2007. "La crémation parmi les pratiques funéraires du Néolithique récent final en France. Méthodes d'étude et analyse de sites," Bulletins et mémoires de la Société d'Anthropologie de Paris 19(3-4): 195-220.

Gilbert, L. 2008. "SIG et transformations, de l'archéologie de l'établissement," Altérités 5(1): 65-82.

Gonçalves, V. S. 1999. "Reguengos de Monzaras. Territorios megaliticos," Camarra municipal de Reguengos de Monsaras.

Grévin, G. 2002. "Les crémations en Inde et au Népal. Approche ethnopharmacologique," in V. Bouiller and G. Tarabout, eds. Images du corps dans le monde Hindou. Paris: édition du CNRS, 499-506.

Guy, H., and C. Masset. 1991. "Procédure de condamnation d'une allée couverte Seine Oise Marne (Méréaucourt, Somme)," Bulletin de la Société Préhistorique de Française 88(9): 282-288.

Guillon, F. 1987. "Brûlés frais ou brûlés secs?" in H. Duday and C. Masset, eds., Anthropologie physique et archéologie: méthodes d'étude des sépultures. Actes du colloque de Toulouse (4, 5 et 6 novembre 1982). Paris: Edition du CNRS, 89-104.

Guillot, H., G. Billand, and I. Le Goff. 1996. "Les éléments en bois du monument funéraire du prieuré à Lacroix-Saint-Ouen (Oise)," Bulletin de la Société Préhistorique Française 93(3): 408-412.

Herrmann, B. 1972. "Das Combe Capell-Skelet. Eine Untersuchung der Brandreste unter Berücksichtigung thermoinduzierter Veränderungen am Knochen," Ausgrabungen in Berlin 3: 7-69.

Hermann, N. P., and J. B. Devlin. 2008. "Assessment of Commingled Human Remains Using a GIS-Based Approach," in B. Adams and J. Byrd, eds., Recovery, Analysis, and Identification of Commingled Human Remains. Totowa, NJ: Humana Press, 257-269.

Hermann, N., J. B. Devlin, and D. Pollack. 2005. "GIS Analysis Of The Cremated Skeletal Material From The Walker-Noe Site, Kentucky," American Journal of Physical Anthropology Supplement 40: 115

Hertz, R. 1907. "Contribution à une étude sur la représentation collective de la mort," L'année sociologique, 1(10): 48-137.

Holager, J. 1970. "Thermogravimetric Examination on Enamel And Dentin," Journal of Dental Research 49(3): 546-548.

Jagu, D. 1996. "Deux Dolmen et un menhir... Ou l'espace funéraire post-sépulcrale de Changé à Saint-Piat (Eure et Loire)," Bulletin de la société Préhistorique Francaise 93(3): 413-417.

Kinnes I. 1992. Non megalithic long borrows and allied structures in the British Neolithic. London: British Museum, Occasional Paper 52.

Leclerc, J. 1987. "Procédures de comdemnation dans les sépultures collectives Seine-Oise-Marne," in H. Duday and C. Masset, eds., Anthropologie physique et archéologie: méthodes d'étude des sépultures. Actes du colloque de Toulouse (4, 5 et 6 novembre 1982). Paris: Edition du CNRS, 89-104.

Leclerc, J. 1995. "Bazoches sur Vesles (Aisne)," in C. Masset and P. Soulier, eds., Allées couvertes et autres monuments funéraires $d u$ Néolithique en France de l'Ouest. Catalogue de l'exposition allées sans-retours. Paris: Errance, 137-138.

Leclerc, J. 1996. "Analyse spatiale des sites funéraires néolithiques," in G. Auxiette, L. Hachem, B. Robert, eds., Espaces physiques espaces sociaux dans l'analyse interne des sites du Néolithique à l'Age du Fer, 119e congrès CTHS en 1994. Amiens: Editions du CNRS, 397-405.

Leclerc, J., and J. Tarrete. 1988. "Sépulture," in A. Leroi-Gourhan, ed., Dictionnaire de la Préhistoire. Paris: Presses Universitaires de France, 963-964.

Lecornue, J., C. Belimi, S. Chevrier, C. Gaston, A. Goutelard, L. Jacottet, R. Labeaune, J. B. Lajoux, K. Meunier, A. Supryk, and S. Thiol. 2009. Le site de 'La Truie Pendue' à PassyVéron (Yonne), Étude Néolithique, 4. Dijon: Service Regional d'Archéologie Bourgogne.

Le Goff, I. 1998. De l'os incinéré aux gestes funéraires. Essai de palethnologie à partir des vestiges de la crémation. Unpublished Ph.D. dissertation, Université Paris I, Paris.

Le Goff, I., G. Billant, and H. Guillot, 1995. "La Croix Saint-Ouen (Oise) une sépulture collective S.O.M. Incendiée?" Bulletin de la Société Préhistorique Française 92(2): 261-265.

Le Goff, I., G. Billand, and H. Guillot. 2002. "Histoire d'une sépulture collective néolithique incendiée (France)," in M. A. Rojo Guerra and M. Kunst, eds., Sobre el Significado del Fuego en los Rituales Funerarios del Neolitico. Valladolid: Universidad de Valladolid, 127-146.

Lenorzer, S., 2006. "Pratiques Funéraires du Bronze Final IIIB au Premier Âge du Fer en Languedoc Occidental et MidiPyrénées: Approche Archéo-Anthropologiques des Né- cropoles à Incinération," Unpublished Ph.D. dissertation, Université Bordeaux I, Bordeaux.

Le Roy, M., S. Rottier, C. de Becdelievre, S. Thiol, C. Coutelier, A.M. Tillier. 2014. "Funerary Behaviour Of Neolithic Necropolises And Collective Graves In France. Evidence From Gurgy 'Les Noisats' (Middle Neolithic) And Passy/ Véron 'La Truie Pendue' (Late Neolithic)," Archaologischeskorrespondenzblatt 44(3): 337-352.

Lisowski, F. P. 1968. "The Investigation of Human Cremations," in T. Bielickiand and K. Saller, eds., Anthropologie und Humangenetik, Festschrift für Karl Saller. Stuttgart: Gustav Fischer, 76-82

McKinley, J. I. 1994. The Anglo-Saxon Cemetery at Spong Hill, North Elmham, Part VIII: The Cremations. Norfolk: Field Archaeology Division, Norfolk Museums Service. 
Mayne Correia, P. M. 1997. "Fire Modification of Bone: A Review of the Literature," in W. D. Haglund and M. H. Sorg, eds. Forensic Taphonomy. The Fate of Human Remains. CRC Press: Boca Raton, 275-293.

Marean, C. W., Y. Abe, P. J. Nilssen, and E. C. Stone. 2011 "Estimating the Minimum Number of Skeletal Elements (MNE) in Zooarchaeology: A Review and a New ImageAnalysis GIS Approach," American Antiquity 66(2): 333-348.

Masset, C. 1992. "Une solution pour le mystère d'Hérouval," Bulletin de la Société Préhistorique Française 89(8): 227-228.

Masset, C. 1995. "Sur la stratigraphie de La Chaussée-Tirancourt," Revue archéologique de Picardie 9: 135-139.

Masset, C. 2002. "Ce qu'on sait, ou croit savoir, du rôle du feu dans les sépultures collectives néolithiques," in M. A. Rojo Guerra and M. Kunst, eds., Sobre el Significado del Fuego en los Rituales Funerarios del Neolitico. Valladolid: Universidad de Valladolid, 9-20.

Masset, C., J. Pelegrin, H. Plisson, A. Blin, F. Mazhoud, D. Jagu, M. Girard. 2013. "L'allée couverte du bois d'Archemont à Méréaucourt (Somme)," Gallia Préhistoire 55: 73-179.

Morel, M. 1869. "Note sur la découverte à Lignon d'une sépulture de l'âge de la pierre polie," Société des Sciences et des Arts de Vitry-le-François III 96: 103.

Müller, F., P. Duhamel, A. Augereau, and G. Depierre. 1997. "Une nouvelle nécropole monumentale Cerny à Gron 'Les Sablons' (Yonne)," in C. Jeunesse, ed., Le Néolithique danubien et ses marges entre Rhin et Seine, actes du 22ème colloque interrégional sur le Néolithique. Strasbourg: Suppléments aux Cahiers de l'APRAA, 103-133.

Müller, D. W., and H. Stahlhofen. 1981. "Zwei Kollektivgraber aus dem Nordharzvorland," Jahresschr-ftfür Mitteldeutshe Vorgeschichte 63: 27-68.

Nawrocki, S. P. 2003. "Experimental Burning of a Dry Human Cranium," Abstracts of the 10 Midwest Bioarcheology and Forensic Anthropology Association Conference. Chicago: Loyola University.

Prampart J.-Y. 1983. "Pont-sur-Yonne 'Bas des Renardières': sépulture SOM, habitat de la Tène et vestiges voisins," Bull. Soc. Archéo et Cult de Pont-sur-Yonne 6: 17-20.

Périnet, G. 1982. "Détermination des températures de cuisson des ossements humains," Dossiers Histoire et Archéologie 66: 96-97.

Regert, M., M. F. Guerra, and I. Reich. 2006. "Physicochimie des matériaux du patrimoine culturel, partie 1," Techniques de l'ingénieur 3781: 1-21.

Rojo Guerra, M. A., and M. Kunst. 1999. "La Pena de la AbuelaUn enterramiento monumental neolitico sellado por la accion del fuego," Revista de Arqueologia 220: 12-19.

Rojo Guerra, M. A., and M. Kunst. 2002. Sobre el Significado del Fuego en los Rituales Funerarios del Neolitico. Valladolid: Universidad de Valladolid.

Sauzade, G. 1988. "Le dolmen II de San-Sébastien, Communes de Plan-de-la-Tour et Sainte-Maxime (Var), Réflexion sur les pratiques de l'inhumation dans les sépultures collectives provençales," Gallia Préhistoire 30: 119-143.

Schmit, E. 1892. "Sépulture Néolithique de Châlon-sur-Marne," Bulletin de la société d'anthropologie de Paris. 188-191.

Shipman, P., G. Foster, and M. Schoeninger. 1984. "Burnt Bones And Teeth: An Experimental Study Of Color, Morphology, Crystal Structure And Shrinkage," Journal of Archaeological Science 11: 307-325.

Schultz, J. J., M. W. Warren, and J. S. Krigbaum. 2008. "Analysis of Human Cremains: Gross And Chemical Methods," in C. W. Schmidt and S. A. Symes, eds., The Analysis of Burned Human Remains. London: Academic Press, 75-95.

Susini, A. 1988. Étude des caractéristiques biophysiques des tissus calcifiés humains soumis à des traitements thermiques:
Applications anthropologiques et médicales. Unpublished Ph.D. dissertation, Université de Genève, Genève.

Stiner M. C., S. L. Kuhn, S. Weiner, and O. Bar-Yosef. 1995. "Differential Burning, Recrystallization, and Fragmentation of Archaeological Bone," Journal of Archaeological Science 22: 223-237.

Symes, S. A., O. C. Smith, and H. Berryman. 1996. "Bones: Bullets, Bums, Bludgeons, Blunders, And Why (Workshop)," Proceedings of the American Academy of Forensic Sciences 2: 10-11.

Symes, S. A., C. W. Rainwater, E. N. Chapman, D. R. Gipson, and A.L. Piper. 2008. "Patterned Thermal Destruction of Human Remains In A Forensic Setting," in C. W. Schmidt and S. A. Symes, eds., The Analysis of Burned Human Remains. London: Academic Press, 15-54.

Tchérémissinoff, Y., and E. Leal. 2014. "Une sépulture collective du groupe de Ferrières en maison funéraire sur cave dans la plaine Montpelliéraine: premières considérations à l'issue de la fouille de la Cavalade/Mas Rouge. 'De la tombe au territoire" 11e Rencontres Méridionales de Préhistoire Récente Montpellier (Hérault). Préactes. Montpellier: RMPR.

Théry-Parisot, I., and S. Costamagno. 2005. "Propriétés combustibles des ossements. Données expérimentales et réflexions archéologiques sur leur emploi dans les sites paléolithiques," Gallia Préhistoire 47: 235-254.

Thiol, S., S. Chevrier, R. Labeaune, E. Boitard-Bidaut, J. Clerget, J. Lecornue, B. Ligouis, A. Goutelard, A. Desbat, and C. Malette. 2010. Passy-véron (89) Volume 9. Rapport final d'opération, INRAP. Dijon: SRA Bourgogne.

Thomas, L. V. 1980. Le cadavre: de la biologie à l'anthropologie. Bruxelles: Complexe.

Thurman, M. D., and L. J. Willmore. 1980. "A Replicative Cremation Experiment," North American Archaeologist 2(4): 275-283.

Thompson, T. J. 2005. "Heat-induced Dimensional Changes in Bone and their Consequences for Forensic Anthropology," Journal of Forensic Science 50: 1008-1015.

Wahl, J. 1981. "Beobachtungen zur Verbrennung Menschlicher Leichname," Archäologisches Korrespondenzblatt 11: 271-279.

Walker, P. L., K. W. P. Miller, and M. S. Richman. 2008. "Time, Temperature, and Oxygen Availibility: An Experimental Study of the Effects of Environmental Conditions on the Color and Organic Content of Cremated Bone," in C. W. Schmidt and S. A. Symes, eds., The Analysis of Burned Human Remains. London: Academic Press, 109-128.

Weitzel, M. A., and H. G. McKenzie. 2008. "Fire as a Cultural Taphonomic Agent: Understanding Mortuary Behavior at Khuzhir-Nuge XIV, Siberia," in C. W. Schmidt and S. A. Symes, eds., The Analysis of Burned Human Remains. London: Academic Press, 185-201.

Valera, A.C., A. M. Silva, C. Cunha, and L. S. Evangelista. 2014. "Funerary Practices And Body Manipulation At Neolithic And Chalcolithic Perdigões Ditched Enclosures (South Portugal)," in A. C. Valera, ed., Recent Prehistoric Enclosures and Funerary Practices in Europe. Oxford: Archaeopress, 37-57.

Van Gennep, A. 1960. Rites Of Passage. London: Routledge.

Van Viet. 1980. "Les sédiments carbonatés: une ou plusieurs techniques de préparations?" in C. Masset and J. F. Baratin, eds., La sépulture à incinérations de Maison Rouge à Montigny (Loiret). Etude Néolithique de la région centre, actes du $5^{\mathrm{e}}$ colloque interrégional sur le Néolithique - Saint-AmandMontrond 1977. Saint-Amand-Montrond: Association des Amis du Musée Saint-Vic, 141-147.

Warren, M. W., and J. J. Schultz. 2002. "Post-cremation taphonomy and artifact preservation," Journal of Forensic Science 47: 656-659. 